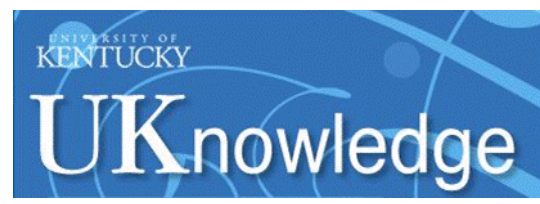

University of Kentucky

UKnowledge

\title{
Redistribution Under the Current Social Security System
}

Kathryn L. Moore

University of Kentucky College of Law, kmoore@uky.edu

Follow this and additional works at: https://uknowledge.uky.edu/law_facpub

Part of the Retirement Security Law Commons

Right click to open a feedback form in a new tab to let us know how this document benefits you.

\section{Recommended Citation}

Kathryn L. Moore, Redistribution Under the Current Social Security System, 61 U. Pitt. L. Rev. 955 (2000).

This Article is brought to you for free and open access by the Law Faculty Publications at UKnowledge. It has been accepted for inclusion in Law Faculty Scholarly Articles by an authorized administrator of UKnowledge. For more information, please contact UKnowledge@lsv.uky.edu. 


\section{Redistribution Under the Current Social Security System}

Notes/Citation Information

University of Pittsburgh Law Review, Vol. 61, No. 4 (Summer 2000), pp. 955-990

This article is available at UKnowledge: https://uknowledge.uky.edu/law_facpub/103 


\title{
REDISTRIBUTION UNDER THE CURRENT SOCIAL SECURITY SYSTEM
}

\author{
Kathryn L. Moore*
}

Table of Contents

I. Introduction ........................................ 956

II. How the Current Social Security System Lifts the Elderly Out of Poverty ..................................... 959

III. How the Current Social Security System Redistributes Income .................................................. 960

A. Payout of Benefits ................................ 961

B. Progressive Benefit Formula ........................ 965

C. Disability Benefits ............................... 966

1. Progressive Benefit Formula .................... 966

2. Likelihood of Collecting Disability Benefits ....... 967

a. Women ...................................... 967

b. Minorities................................... 969

c. Lower-Wage Workers...................... 972

3. Conclusion ....................................... 974

D. Auxiliary Benefits.................................. 975

1. Spouse and Surviving Spouse Benefits........... 976

2. Dependent Child Benefits ...................... 980

3. Conclusion ...................................... 981

IV. Conclusion ............................................ 982

Appendix............................................. 983

A. Funding Under the Current Social Security System .... 983

B. Benefits Under the Current Social Security System .... 985

* Associate Professor of Law, University of Kentucky, College of Law.

The author is grateful to Richard C. Ausness, Karen C. Burke, Jonathan Barry Forman, Michael P. Healy, Brian A. Jones, Robert J. Myers, and John M. Rogers for their comments on earlier drafts and to Lisa Graening, Carol Parris, and Amy Shoemaker for their research assistance. 


\section{INTRODUCTION}

Arguably the most successful program of the modern welfare state, ${ }^{1}$ Social Security ${ }^{2}$ has been enormously successful in lifting the elderly out of poverty. ${ }^{3}$ Thirty years ago, almost $30 \%$ of the elderly were in poverty, a poverty rate that was more than twice as high as the rate for the population as a whole. ${ }^{4}$ Today, in contrast, only about $12 \%$ of the elderly are subject to poverty, a rate that is about the same as the rest of the adult population. ${ }^{\mathrm{s}}$

Yet demographic changes in American society make reform of the program appear inevitable. ${ }^{6}$ In less than ten years, the first wave of baby boomers will begin to retire and become the elder boom. ${ }^{7}$ The baby boom generation is more than $50 \%$ larger than the retired generation it now supports. By contrast, the baby boom generation will be supported

1. See generally Kathryn L. Moore, Privatization of Social Security: Misguided Reform, 71 TEMP. L. REv. 131, 131 n.1 (1998) (listing authorities that discuss the success of the program).

2. For purposes of this article, the term Social Security will be used in its generally accepted manner as referring only to the cash benefits provided by the Old-Age, Survivors, and Disability Insurance ("OASDI") program. The Old-Age and Survivors Insurance ("OASI") provides benefits for retired workers and their spouses and children and to survivors of deceased workers. See Martynas A. Ycas, The Issue Unrevolved: Innovating and Adapting Disability Programs for the Third Era of Social Security, SOC. SECURITY Bull., vol. 58, no. 1 at 48, 48-49 (1995). The Disability Insurance ("Dl")-program provides benefits for disabled workers and their spouses and children and pays for rehabilitation services for the disabled. See id. For a discussion of other possible definitions of the term Social Security, see Robert J. Myers, Social Security 5-6 (4th ed. 1993); Robert M. Ball. SOCIAL SECURITY TODAY AND TOMORROW 1-4 (1978).

3. See generally Center on Budget and Policy Priorities, Strengths of the Safery Net: How the EITC, Social Security, and Other Government Programs Affect Poverty (pt. 5) (Mar. 9, 1998) <http:/I www.cbpp.org/snd98-rep.htm> (discussing effectiveness of Social Security in lifting elderly out of poverty).

4. 1 1994-1996 Advisory Council on SOC. Security Rep.: Findings and Recommendations 88 (1997) [hereinafter 1994-1996 ADVISORY COUNCIL REPORT].

5. See id.; see also U.S. Gen. Acct. OfF., Social SecurtTy: Different Approaches for AdDRESSing Program Solvency 2, 12 (GAO/HEHS-98-33 July 1998) (noting that "[s]ince Social Security's creation, poverty rates for the elderly have fallen from an estimated $50 \%$ in 1935 to $11 \%$ today," and that "[t]he Social Security program is one reason that poverty rates among the nation's elderly have fallen dramatically .....") [hereinafter DIFFERENT APPROACHEs]; Steven H. Sandell \& Howard M. Iams, Reducing Women's Poverty by Shifting Social Security Benefits from Retired Couples to Widows, $16 \mathrm{~J}$. OF POL'Y ANALYSIS AND MGMT. 279, 281 (1997) ("The elderly were at least as well off in the 1980s as the nonelderly when measured by income level.") (citations omitted); Sheldon Danziger et al., Income Transfers and the Economic Status of the Elderly, in ECONOMiC TRANSFERS IN THE UNITED STATES 239 (Marilyn Moon ed., 1984) (comparing economic status of elderly with that of nonelderly).

6. See Sylvester J. Schieber, A Framework and Proposal for Social Security Reform, 22 WASH. Q. 157, 157 (1999) ("Social Security reform is a certainty.").

7. The eldest of the baby boom generation will reach early retirement age (62) in 2008. See DIFFERENT APPROACHES, supra note 5, at 18. 
by relatively smaller generations. While there are nearly five working-age individuals to support each American over age 65 today, there will be fewer than three by 2029 , when the last baby boomer turns $65 .^{8}$ Indeed, the Board of Trustees of the Federal Old-Age and Survivors and Disability Insurance (OASDI) Trust Funds predicts that unless corrective action is taken, Social Security benefit payments will exceed dedicated tax revenues by the year 2015, and the Social Security program will become insolvent-unable to pay promised benefits in full-by the year 2037.9

As a result of these dire predictions, proposals to reform Social Security abound. They range from moderate tinkering with the current system, such as by raising the normal retirement age, to fundamentally restructuring the system by privatizing it; that is, by providing all or part of benefits through pre-funded individual accounts. ${ }^{10}$ Just as the proposals range widely, their effect on specific subpopulations vary greatly.

Recently policymakers have begun to express concern with how Social Security reform would likely affect specific subpopulations. For instance, President Clinton expressly referred to the needs of lower-income beneficiaries in discussing Social Security reform. ${ }^{11}$ Similarly, Jane L. Ross, Director, Income Security Issues, Health, Education, and Human Services Division of the General Accounting Office has said, "In addition to examining the effects of reform proposals on all retirees generally, attention should be paid to how they affect specific subpopulations, especially those that are most vulnerable to poverty, including women,

8. See American Academy of Actuaries, Financing the Retirement of Future Genera. tions: The Problem And Options for Change 30 (1998). For an excellent comprehensive discussion of why Social Security faces long-term funding difficulties, see id. at 6-10.

9. See Board of Trustees, Fed. Old-Age and Survivors Ins. and Disability Ins. Trust Funds, 2000 Annual Report 3-4 (2000) (using figures that refer to the combined OASDI trust funds).

10. Cf. AMERICAN ACADEMY OF ACtUARIES, supra note 8, at 26 ("The first task for Social Security is to determine whether to make fundamental changes in the underlying philosophy of the program or to preserve the system in its current form. In the context of the current debate, fundamental reform means providing all or part of benefits through individual accounts that are pre-funded through the use of market-based securities.").

11. See Elizabeth A. White, Clinton Kicks Off National Dialogue On Steps to Strengthen Social Security, 25 Pens. \& Ben. Rep. (BNA) 857, 858 (Apr. 13, 1998) ("Social Security must continue to protect the disabled and low-income beneficiaries"). Vice President Gore reaffirmed this commitment at a July 1, 1998, public forum on Social Security in Cranston, R.I. Gore Urges Congress to Take Steps to Reform Social Security in 1999, 25 Pens. \& Ben. Rep. (BNA) 1549, 1549 (July 6, 1998) ("Gore said any solution strengthening the system should keep it universally fair and protect the disabled and low-wage workers, particularly women"). Moreover, on October 29, 1998, President Clinton and Vice President Gore held a roundtable discussion at the White House on women and retirement security. See The White House: Remarks at roundtable Discussion on Women and Retirement Security, M2 PRESSWIRE, Oct. 29, 1998, available in Westlaw, ALL News PLuS. 
widows, minorities, and the very old." 12

Determining how Social Security reform would likely affect specific subpopulations presupposes an understanding of how the current Social Security System redistributes income. Yet determining how the current system redistributes income is no easy task. It "involves many judgments, and is not easily answered with general aggregate numbers." 13 Commentators uniformly agree that until now, Social Security has effectively redistributed income from the working generations to the retired generations, ${ }^{14}$ but they vigorously debate how effective the program has been in redistributing income within cohorts. ${ }^{15}$

This Article describes how the current system redistributes income. ${ }^{16}$ The Article does not attempt to develop a mathematical model to generate an aggregate number. Such an undertaking would go well beyond the scope of a law review article. ${ }^{17}$ Instead, the Article identifies and discusses the principal factors that are most relevant in determining how the current system redistributes income within generations. ${ }^{18}$ Since one of the

12. Social Security: Restoring Long-Term Solvency Will Require Difficult Choices 4 (GAO/T-HEHS-98-95 1998) [Testimony Before the Special Committee on Aging, U.S. Senate] (statement of Jane L. Ross, Director, Income Security Issues, Health, Education, and Human Services Division) [hereinafter Difficult CHOICES]. See also White, supra note 11, at 858 (noting that, at Kansas City public forum on Social Security reform, "one recurring theme voiced by policymakers and experts throughout the three sessions was the need to act quickly and with attention to the impact across different generations and within different population sectors in the face of looming demographic challenges the system faces."); David A. Weaver, The Economic Well-Being of Social Security Beneficiaries, with an Emphasis on Divorced Beneficiaries, SOC. SECURITY BUL., vol. 60, no. 4, at 3, 3 (1997) ("One concern of many policymakers will be whether the affected beneficiaries have low economic status.").

13. Staff of House Comm. on Ways and Means, 105th Cong., 1998 Green Book: Background Material and Data on Programs Within the Jurisdiction of the Comm. ON Ways and Means 86 (Comm. Print 1998) [hereinafter 1998 Green BOOK].

14. See Kathryn L. Moore, Redistribution Under a Partially Privatized Social Security System, 64 BROOK. L. REV. 969, 974-75 and authorities cited therein.

15. See generally id. at 988 n.81 and authorities cited therein.

16. This author uses the foundation laid out in this Article to analyze how partial privatization of Social Security would likely affect women, minorities, and lower-income workers in Kathryn $\mathbf{L}$. Moore, Partial Privatization of Social Security: Assessing Its Effect on Women, Minorities, and Lower-Income Workers, 65 Mo. L. REv. 341 (2000).

17. For a discussion of a sophisticated computer model that was developed specifically for this purpose, see Kelly A. Olsen et al., Employee Benefit Res. Inst., IsSue Brief No. 195, How Do Individual Social. Security Accounts Stack Up? AN Evaluation Using the EBRI-SSASIM2 Policy Simulation MOdel (1998) (using model to show cost, benefit, national saving, and growth projections under five options for reforming Social Security).

18. Some economists have viewed Social Security as an annual tax transfer program that redistributes income from the relatively affluent working population to the relatively less affluent retired population. More commonly, however, economists have viewed Social Security from a lifetime perspective and treat Social Security contributions as mandatory savings for retirement. See Moore, 
fundamental purposes behind Social Security is to provide for progressive redistribution to lift the elderly out of poverty, ${ }^{19}$ and women, minorities, and lower-income workers are at a heightened risk of poverty in old age,$^{20}$ the Article focuses on how the current system affects these groups.

The Article begins by describing the role Social Security has played in lifting the elderly, and particularly members of the at-risk groups, out of poverty. It then analyzes how four elements of the current system: (1) the method by which benefits are paid out; (2) the progressive benefit formula; (3) disability benefits; and (4) auxiliary benefits affect these groups. The Article assumes that the reader has a basic understanding of how the current system operates. For those who would like more details, the Appendix provides an overview of the funding and benefit structure of the current system.

\section{How the Current Social Security System LifTS the Elderly OUT OF POVERTY}

More than $90 \%$ of all "aged units," that is, married couples living together with a spouse aged 65 or older or individuals 65 or older who did not live with a spouse, ${ }^{21}$ received Social Security benefits in 1996.22 Yet the significance of those benefits varied widely. For beneficiaries in the highest quintile of income in 1996, those benefits only represented $21 \%$ of income. ${ }^{23}$ For beneficiaries in the two lowest quintiles, in contrast, they represented $80 \%$ or more of income. ${ }^{24}$ Indeed, while $9 \%$ of aged beneficiaries currently receive total income that falls below the poverty line, ${ }^{25}$ without Social Security, the income of $50 \%$ of aged beneficiaries would fall below the poverty line. ${ }^{26}$ Thus, Social Security has played a significant role in lifting many of the elderly out of poverty.

Overall, older women and minorities are much more likely to be

supra note 1, at 158 n.164 and authorities cited therein. This article applies the lifetime framework in discussing how Social Security redistributes income within generations.

19. See Moore, supra note 14, at 970 n.5, 988,988 n.80.

20. See discussion infra Section II.

21. See Social Security Admin.. Income of the Aged Chartbook, 1996 at ii (May 1998) [hereinafter INCOME CHARTBOOK].

22. See id. at 8 .

23. See id. at 16.

24. See id.

25. See id. at 10. For the current poverty guidelines, see Annual Update of the Health and Human Services Poverty Guidelines, 63 Fed. Reg. 9235, 9236 (1998).

26. See InCOMe Chartbook, supra note 21, at 10. For a more lengthy discussion of the role Social Security plays in the well-being of the elderly, see ERIC R. KINGSON \& Edward D. Berkowitz. Social Security and Medicare: A Policy Primer 71-86 (1993). 
poor than older men and nonminorities. ${ }^{27}$ Nevertheless, Social Security plays an important role in reducing the poverty rates of older women and minorities. For example, while $18 \%$ of nonmarried women beneficiaries aged 65 or over receive total income that falls below the poverty line, without Social Security the income of $62.6 \%$ of these beneficiaries would fall below the poverty line. ${ }^{28}$ Similarly, while $26.2 \%$ of black beneficiaries aged 65 or older receive total income that falls below the poverty line, without Social Security the income of $62.2 \%$ of these beneficiaries would fall below the poverty line. ${ }^{29}$ Likewise, while $22.2 \%$ of Hispanic beneficiaries aged 65 or older receive total income that falls below the poverty line, without Social Security the income of $60.5 \%$ of these beneficiaries would fall below the poverty line. ${ }^{30}$ Thus, not only does Social Security play an important role in generally lifting the elderly out of poverty, but it also plays an essential role in lifting many members of the atrisk groups out of poverty in old age.

\section{How the CurRent Social Security System Redistributes INCOME}

Until now, Social Security has effectively redistributed income from the working generations to the retired generations. How effective it has been in redistributing income within cohorts, however, is subject to considerable debate. Advocates of the current system describe it as the country's most successful anti-poverty program. ${ }^{31}$ Critics, in contrast, contend

27. See Difficult Choices, supra note 12 , at 5-6

Women, minorities, and persons aged 75 and older are much more likely to be poor than other elderly persons. For example, compared with $11 \%$ for all elderly persons (age 65 and older) in 1996, poverty rates were $23 \%$ for all elderly women living alone, roughly $25 \%$ for elderly blacks and Hispanics, and $31 \%$ for black women older than $75 \%$. Unmarried women make up more than $70 \%$ of poor elderly households, although they account for only $45 \%$ of all elderly households.

See also How Will Today's Women Fare in Yesterday's Traditional Retirement System? Hearing Before the Subcomm. on Retirement Income and Employment of the House Select Comm. on Aging, 102d Cong. 42 (1992) (providing 1990 data showing disproportionate poverty rates of elderly women, minorities, and individuals over age 75) [hereinafter "Women Fare"].

28. See Social Security Admin., income of the Population 55 or Older, 1996, at 133 tbl. VIII.5 (Apr. 1998).

29. See id.

30. See id.

31. See Women Fare, supra note 27, at 55 (beginning her testimony, Lou Glass, President, Older Women's League, declares, "First let me start by saying that the Social Security system is the most effective antipoverty program America has ever had."). See also Peter M. Wheeler \& John R. Kearney, Income Protection for the Aged in the 21st Century: A Framework to Help Inform the Debate. Soc. Security Bull., vol. 59, no. 2, 3, 5 (1996) ("In the United States, Social Security has been instrumental in bringing about a significant reduction in poverty among the aged. Although the 
that the system is more effective in redistributing income to those least in need than those most in need. ${ }^{32}$ This debate is due principally to the complexity of the system ${ }^{33}$ and the myriad of judgments and factors that must be taken into account in making such a determination. ${ }^{34}$

In order to help resolve this debate, this section identifies and discusses the principal elements ${ }^{35}$ of the current Social Security system that are relevant in determining how Social Security redistributes income. Those elements are: (1) the method by which benefits are paid out; (2) the progressive benefit formula; (3) disability benefits; and (4) auxiliary benefits. In brief, this section shows that one of these four factors, the progressive benefit formula, tends to benefit all three of the at-risk groups, women, minorities, and lower-income workers. The effect of the other three factors, in contrast, is mixed and more complex.

\section{A. Payout of Benefits}

The current Social Security system pays benefits in the form of a life annuity; ${ }^{36}$ that is, it pays retirees a fixed amount per month for life based on a complex benefit formula. ${ }^{37}$ The Social Security system, however, does not take life expectancy into account in calculating benefits

aged poverty rate continues to be higher than in many European countries, it has remained for several years below the poverty rate for the population as a whole.").

32. See, e.g., Peter J. Ferrara, Social. Securtty: The Inherent Contradiction 54-57, 292 (1980).

33. The Appendix offers an overview of how the system is funded and the various benefits it provides.

34. See 1998 GREEN BOOK, supra note 13, at 86.

35. Other factors that may affect redistribution include the regressive manner in which the benefits are financed (flat tax subject to a wage cap) and the limitation of the number of years of employment that are taken into account in calculating benefits. For a discussion of the regressivity of the funding of the program, see, for example, C. Eugene Steuerle \& Jon M. BaKiJa, Retooling Social Security for the 21St Century: Right and Wrong Approaches to Reform $74-75$ (1994); Jonathan Barry Forman, Promoting Fairness in the Social Security Retirement Program: Partial Integration and a Credit for Dual-Earner Couples, 45 TAX LAW. 915, 928-30 (1992). For a discussion of the effect of the limitation of years of employment, see HENRY J. AARON. BROOKINGS INST.. Eco. NOMIC EFFECTS OF SOCIAL, SECURITY 78-80 (1982). For a more comprehensive list of factors that are relevant in determining how Social Security affects blacks, see Patrick Driessen, The Race Factor in Social Security, THE Rev. OF BlaCK POLITICAL ECONOMY 89, 92-95 (Fall 1988) (describing progressivity of benefit formula, disproportionate black participation in disability and survivors' programs, and black family formation as factors purportedly benefitting blacks while describing black mortality rates, black family formation, probability of employment, orientation of Social Security benefit structure, and "lost" quarters as factors that purportedly discriminate against blacks).

36. "An annuity provides a stream of payments for an agreed-upon period of time; a life annuity provides payments for as long as the annuitant is alive . . CONGRESSIONAL BUDGET OfFICE. Social. Security Privatization and the Annuities Market 2 (1998).

37. See infra Appendix Part B for a description of the benefit formula. 
(other than to make actuarial adjustments to the benefits of individuals who begin to collect their benefits before or after the normal retirement age). ${ }^{38}$ As a result, all workers who make identical contributions to the system (and begin to receive benefits at the same age) are entitled to identical monthly payments, ${ }^{39}$ but do not necessarily receive the same lifetime benefits. Rather, workers who live longer receive greater lifetime benefits than do workers who make identical contributions to the system (and begin to receive benefits at the same age) but die sooner. Thus, members of groups that tend to live longer tend to receive more benefits than do members of groups with lower life expectancies.

Women have higher life expectancies ${ }^{40}$ than men, ${ }^{41}$ individuals with lower incomes have lower life expectancies than those with higher incomes, ${ }^{42}$ blacks have lower life expectancies than whites, ${ }^{43}$ and Hispanics $^{44}$ and Asians ${ }^{45}$ have higher life expectancies than whites. Because of

38. See infra Appendix Part B for a discussion of the actuarial adjustment.

39. Auxiliary benefits may result in different total benefits being paid out on behalf of two workers with identical contributions. For a more detailed discussion of the impact of auxiliary benefits, see discussion infra Part III.D.

40. Life expectancy at age 20 or so, rather than birth, is more relevant for these purposes because most individuals do not begin contributing to the social security system until age 20 or after. Arguably, life expectancy at age 65 is more relevant than life expectancy at age 20 because 65 is the age at which most beneficiaries are entitled to receive unreduced benefits. Nevertheless, this section focuses on life expectancy at age 20 rather than age 65 to try to capture, however unartfully, the effects of deaths before age 65, cf. Kilolo Kijakazi, African Americans, Hispanic Americans, and Social Security: The Shortcomings of the Heritage Foundation Reports (Center on Budget and Pol'y Priorities), Oct 8, 1998 (explaining that the Heritage Foundation report understates rates of return African Americans receive from Social Security because it does not take into account probability of death before age 65 ). Regardless of which age is selected, 20 or 65 , the relative differences in life expectancy remain although specific life expectancy changes.

41. For example, white males at age 20 in 1996 could expect to live an additional 54 years while their female counterparts could expect to live an additional 60.3 years. Bureau of the Census, U.S. Dept. of Commerce, U.S. Census Bureau, Statistical Abstract of the United States 1998, 94 tbl. 129 (1998) [hereinafter BUREAU OF Census]. Black males at that age could expect to live an additional 48 years while their female counterparts could expect to live an additional 55.7 years. See id. The gap in gender differences past infancy, however, is quickly narrowing. See Banner Year for U.S. Longevity, STAT. BULL., Oct.-Dec. 1998, at 8 ("Examining gender differences in longevity values past infancy, it becomes apparent that the sex differentials are narrowing rapidly.").

42. Cf. STEUERLE \& BAKIJA, supra note 35, at 115 (describing recent studies that show inverse relationship between income and mortality that is independent of race); HARRIET ORCUTT DULEEP. OCCUPATIONAl EXPERIENCE and SOCIOECONOMIC Variations in MORTaltTy (ORS Working Paper Series No. 65, at 1 (1995) ("[A] strong inverse relationship between socioeconomic status and mortality in the United States has been well documented."); Jonathan S. Feinstein, Relationship Between Socioeconomic Status and Health: A Review of the Literature, 71 Milbank Q. 279 (1993) (finding lower income correlated with lower life expectancy).

43. See Bureau of the Census, supra note 41 , at 94 tbl. 129.

44. There appears to be little data available on life expectancy of Hispanics at age 20. Nevertheless. a number of authorities contend that life expectancy of Hispanics at age 65 is higher than 
these differentials in life expectancy, women, ${ }^{46}$ Hispanics, ${ }^{47}$ and Asians generally benefit from the way in which Social Security pays out benefits while blacks and lower-income workers are relatively disadvantaged. ${ }^{48}$

Some commentators emphasize this differential and contend that the program discriminates against or disfavors blacks ${ }^{49}$ and lower-income

that of whites. Cf. Social SeCurity Admin., Why is Social SeCurity Important for Minority GROUPS? 3 (Apr. 1999) (showing life expectancy at age 65 in 199518.5 years for men of Hispanic origin and 15.7 for their white counterparts and 21.8 years for women of Hispanic origin and 19.1 years for their white counterparts) (hereinafter Social SeCURITY AdMin.]; U.S. GEN. ACCT. OfF., So. Cial Security and Minortties: Current Benefts and Implications of Reform 3 (GAO/T-HEHS99-60 Feb. 1999) ("At age 65, in 1998, . . Hispanic men can expect to live 2.9 years longer than white men. The projections for life expectancy for white . . and Hispanic women at age 65 are 19.5 . . . and $\mathbf{2 2 . 2}$ years, respectively.") [hereinafter IMPLICATIONs]; Kijakazi, supra n.40, at 3 ("Hispanic retirees live longer, on average, than other Americans-the average American who reaches 65 (including both men and women) will live an additional 171/2 years, while the average Hispanic reaching 65 lives an additional 20.5 years.").

One study, however, found that Hispanics have lower life expectancies than whites at all ages, once mortality adjustments are taken into account. See Mark D. Hayward \& Melonie Heron, Racial Inequality in Active Life Among Adult Americans, 36 DEMOGRAPHY 77 (Feb. 1999) (taking into account mortality adjustments, finding that white women aged 20 in 1990 had life expectancy of 60.93 compared with $\mathbf{5 7 . 7 4}$ for their Hispanic counterparts and white men aged 20 in 1990 had life expectancy of $\mathbf{5 4 . 5 9}$ compared with $\mathbf{4 8 . 9 7}$ for their Hispanic counterparts and finding that white women aged 60 in 1990 had life expectancy of 23.58 compared with 21.46 for their Hispanic counterparts and white men aged 60 in 1990 had life expectancy of 19.10 compared with 17.21 for their Hispanic counterparts).

45. According to a study of 7 selected states in 1992, life expectancy of Asian/Pacific Islanders between the ages of 15 and 24 was 66.1 years, while life expectancy of their white counterparts was 61.2 years. Donna L. Hoyer \& Hsiang-Ching Kung, Asian or Pacific Islander Mortality, Selected States, 1992, 46 Monthly Vital Stat. Rep. 1, at 7 tbl. B (1997).

46. Cf. Michael J. Boskin et al., Social Security: A Financial Appraisal Across and Within Generations, 40 NAT'L TAX J. 19 (1987) (finding single women have higher rate of return than single men because of their higher life expectancy); Martha N. Ozawa, Who Receives Subsidies Through Social Security, and How Much?, 27 Soc. WORK: J. NAT'L Ass'N SOC. WORKERS 129, 131 . 32 (1982) (using benefit-contribution ratios for hypothetical workers, contending that for workers retiring at age 65 in 1982, female workers will receive higher subsidies than will male workers due to their higher life expectancy). See generally Edmund Outslay \& James E. Wheeler, Separating the Annuity and Income Transfer Elements of Social Security, 57 Accr. R. 716 (1982) (showing that unmarried females receive slightly better rate of retum under Social Security than unmarried males due to their higher life expectancy).

47. See, e.8., Kijakazi, supra note $\mathbf{4 0 .}$

48. Of course, particular individuals may live longer and others die sooner than expected and thus actually receive greater or fewer benefits than expected.

49. See, e.g., Frank G. Davis. The Black Community's Social Security 86-92, 112-13 (1977) (contending that blacks subsidize benefits of whites because of blacks' lower life expectancy): Geoffrey T. Holtz, Note, Social Security Discrimination Against African-Americans: An Equal Protection Argument, 48 HASTINGS L.J. 105, 108-110 (1996) (contending that Social Security discriminates against blacks because of their lower life expectancy). See also Deroy Murdock, How Sorial Security is Rigged Against Blacks, WASH. TIMEs, July 29, 1997, at A17, available in 1997 WL 3679250 (contending that Social Security is a bad deal for black Americans because of their lower 
workers. ${ }^{50}$ Most analysts, however, contend that the program, in its entirety, effectively redistributes to blacks and lower-wage workers even though life expectancy differentials reduce redistribution to blacks and lower-wage workers. ${ }^{51}$ In any event, the method by which benefits are paid out clearly tends to favor women, Hispanics, and Asians and to disadvantage blacks and lower-income workers.

life expectancy); Pete du Pont, Is Social Security Fair to Black Males? (Sept. 19, 1986) <http:// www.public-policy.org/ncpa/oped/dupont/sep 1996.html>; Walter Williams, Little Abuses Add Up to Height of Injustice, CINCINNAT! ENQUIRER, Nov. 20, 1994, at F3, available in 1994 WL 6302475 ("The only official racism left in America is Social Security racism."); Editorial, The '80s in Black and White, ORANGe CounTY REg., July 28, 1992, at B08, available in 1992 WL 6366287 (contending that Social Security is "a massive robbery from black taxpayers to white recipients" because black men have lower life expectancies than white men). See also StafF of HOUSE COMM. ON WAYS and Means, 96th Cong, Report of the 1979 advisory Councll on Social Security 125 (Comm. Print 1979) [hereinafter AdvISORY COUNCIL ON SOCIAL SECURITY] (noting that some critics allege that Social Security is unfair to minorities because of their lower life expectancies and earlier entry into workforce).

50. See, e.g., Michael Tanner, Privatizing Social Security: A Big Boost for the Poor, Soc. SECurity Privitzzation No. 4 (The Cato Project on Soc. Security Privatization) July 26, 1996 (pointing to, among other things, mortality differential and contending that current Social Security system is a bad deal for the poor). Cf. David M. Garrett, The Effects of Differential Mortality Rates on the Progressivity of Social Security, 33 ECON. INQUIRY 457 (1995) (finding lower life expectancy of poorer people substantially decreases progressivity of Social Security system); CoNSTANTUN W.A. Panis \& Lee A. Lillard, Social Security: Equity, Adequacy, Reforms 12 (Rand Documented Briefing: Labor and Population 1996) (finding that once lower life expectancy taken into account, Social Security much less progressive than weighted benefit formula would suggest).

51. See Implications, supra note $\mathbf{4 4}$, at 3 ("The consensus among researchers is generally that the progressivity of the benefit formula outweighs the negative effect of lower life expectancy for blacks in terms of what they . . contribute."). See, e.g., STEUERLE \& BAKUA, supra note 35, at 11519 (finding that mortality differentials weaken Social Security's progressivity but do not eliminate it); KINGSON \& BERKOWITZ, supra note 26, at 125-126 (recognizing that because of lower life expectancies, members of minorities groups are less likely to receive retirement benefits but contending that this is offset by three factors: (1) minorities are more likely to receive disability and survivors' benefits; (2) minorities are more likely to benefit from Social Security's weighted benefit formula; and (3) Social Security represents a larger portion of minorities' retirement income); AARON, supra note 35, at 80

On balance, it is clear that such factors as differential mortality and age of entry offset, but do not eliminate, the progressivity of the social security benefit formula, that survivors and disability insurance reinforce it, and that social security has provided relatively larger lifetime wealth increments to cohorts with low earnings and, within those cohorts, to workers with low earnings.

Advisory COUNCIL on Social SecurtTy, supra note 49, at 125 (acknowledging that lower life expectancy of minorities means they are less likely to receive Social Security retirement benefits but contending that this factor is offset by their greater propensity to receive disability and survivor benefits and benefit from Social Security's weighted benefit formula). 


\section{B. Progressive Benefit Formula}

Social Security uses a progressive benefit formula to calculate benefits; that is, as a person's average earnings increase, the formula replaces a decreasing percentage of adjusted average earnings. ${ }^{52}$ This progressive benefit formula is specifically designed to redistribute income from higher-paid workers to lower-paid workers. Since women and minorities, other than Asians, ${ }^{53}$ tend to be lower-paid, ${ }^{54}$ the progressive benefit formula generally favors all three of the at-risk groups (with the exception of Asians).

Whether the progressive benefit formula is sufficient to override the adverse impact of the lower life expectancies of blacks and lower-income workers is subject to debate. Most commentators contend that Social Security's progressive benefit formula, in conjunction with its disability5s and survivor ${ }^{56}$ benefit provisions, overrides the adverse effect of life expectancy differentials and ensures that the system as a whole effectively redistributes income to minorities and lower-income workers. ${ }^{57} \mathrm{~A}$ few commentators, however, suggest that the progressive benefit formula is not sufficient to offset the adverse effect of lower life expectancy. ${ }^{58} \mathrm{Re}$ gardless of this debate, the progressive benefit formula clearly tends to

52. See infra Appendix Part B.

53. Unlike other minority groups, Asian/Pacific Islanders have the highest median income of any racialethnic group in the United States. BUREAU OF THE CENSUS, U.S. DEPT. OF COM., MONEY IN. come for the Untred States: 1997 Current Population Reports, Consumer Income vii tbl. A (1998) (showing that median income in 1997 was $\$ 45,249$ for Asian/Pacific Islanders, $\$ 40,577$ for whites not of Hispanic origin, $\$ 26,628$ for Hispanics, and $\$ 25,050$ for blacks) [hereinafter 1997 CURRENT INCOME REPORTS].

54. See, e.g., 1997 CURRENT INCOME RePorTs, supra note 53, at vii tbl. A, 28-29 tbl. 7 (reporting that in 1997 the median earnings of full-time, year-round working women was $74 \%$ of that of men $(\$ 24,973$ versus $\$ 33,674)$ and that the median income of white-non-Hispanic men was $\$ 36,118$, black men was $\$ 26,897$, and men of Hispanic origin was $\$ 21,799$ while the median income of white-non-Hispanic women was $\$ 26,470$, black women was $\$ 22,764$, and women of Hispanic origin was \$19,676). See also Dorothy A. Brown, Race, Class, and Gender Essentialism in Tax Literature: The Joint Return, 54 WASH. \& LEE L. REv. 1469, 1489 (1997)(providing data from 1990 to show that married white men earn the highest salaries, followed by married African-American men, followed by married white women, followed by married African-American women).

55. See discussion infra Part III.C.

56. See discussion infra Part III.D.

57. See supra notes $49-51$ and accompanying text.

58. See, e.g., Holtz, supra note 49, at 110 (acknowledging that Social Security's weighted benefit formula benefits blacks but contending that it does not overcome adverse effect of their lower life expectancy and regressivity of Social Security's flat tax that is capped for higher-income workers); TANNER, supra note 50, at 1 (recognizing that lower-income workers benefit from Social Security's weighted benefit formula but maintaining that system as a whole is a bad deal for the poor). 
favor all three of the at-risk groups, women, minorities (other than Asians), and lower-income workers.

\section{Disability Benefits}

Not only does Social Security pay old-age benefits to retired workers, but it also pays disability benefits to qualified disabled workers. Although most studies of Social Security's redistributive effects disregard the program's disability benefits, ${ }^{59}$ those benefits may in fact play an important role in redistributing income. ${ }^{60}$

Two factors are relevant in determining the redistributive effects of Social Security's disability benefit provisions: (1) the progressive benefit formula on which the benefits are based; and (2) the likelihood of a particular individual collecting those benefits.

This section explains that the first factor, the progressive benefit formula, tends to favor all three of the at-risk groups while the second factor, the likelihood of collecting disability benefits, tends to benefit two of the at-risk groups, minorities and lower-wage workers, and disadvantage the third, women (with the possible exception of black women). The section thus shows that Social Security's disability benefit provisions clearly tend to favor minorities and lower-wage workers while its effect on women is mixed.

\section{Progressive Benefit Formula}

Like old-age benefits, disability benefits are based on a progressive

59. See IMPLICATIONS, supra note 40 , at 4 \& n.6 (noting that none of the currently available studies have included disability or survivor benefits in their assessment of the benefits minorities receive from Social Security but that the GAO is working with a data set to provide that information); Dean R. Leimer, Historical Redistribution Under the Social Security Disability Insurance Program, SOC. SECURITY BuLl, vol. 61, no. 3, at 3 (1998) ("[R]elatively few studies have focused on redistribution under the Social Security Disability Insurance (DI) program."); AARON, supra note 35, at 80 (noting that studies of Social Security's redistributive effects that focused on entry date of work and life expectancy did not adequately take into account survivor or disability insurance benefits); JMM Saxton, Payroll Taxes and the Redistribution of Income: A JoInt Economic Committee Study 4 n.6 (July 1997) ("All of the results are limited to the OASI program because few studies have been conducted on the DI program."). See also Kijakazi, supra note 44, at 3, 5, 23 (criticizing Heritage Foundation report promoting privatization of Social Security for failing to take into account disability benefits).

60. See authorities cited in supra note 51. See also Jon Bakija \& C. Eugene Steuerle, Social Security Disability Insurance: Fiscal Imbalance and Lifetime Value (The Urban Inst.) July 1993, at 13-19 (finding from ex ante insurance perspective that estimated redistribution of SSDI program for 1965 birth cohort moderately progressive). 
benefit formula. ${ }^{61}$ Thus, all other things being equal, Social Security's disability benefits treat individuals with lower earnings more favorably than those with higher earnings because they replace a higher percentage of lower wages. ${ }^{62}$ Since women and minorities (other than Asians) tend to be lower paid, the disability program's progressive benefit formula tends to favor all three of the at-risk groups (with the exception of Asians).

\section{Likelihood of Collecting Disability Benefits}

All other things being equal, Social Security's disability benefits should also favor those who are most likely to collect those benefits. ${ }^{63}$ This section shows that women, with the possible exception of black women, are less likely to collect the benefits than are men, while minorities and lower-income workers are more likely to collect the benefits than are their nonminority and higher-income counterparts.

\section{a. Women}

Women tend to become disabled less frequently than do men. For example, in 1988, women of any given age or level of schooling were almost always less likely to report work disabilities than were their male counterparts. ${ }^{64}$ This relationship remained relatively constant for the entire period between 1981 and 1988 and thus appears to represent a long term trend. ${ }^{65}$

Because women are less likely to become disabled than men, women are less likely to collect Social Security disability benefits than are men. While women represented $58 \%$ of the total adult Social Security beneficiary population and $48 \%$ of the adult retired worker beneficiary population in 1997 , they only represented $41 \%$ of the adult disabled

61. See infra Appendix Part B.

62. Cf. Leimer, supra note 59 , at 8 ("In general, lower earnings result in more favorable treatment under the DI program, ceteris paribus, because of the progressive benefit formula that provides higher replacement rates for workers with lower average lifetime eamings.").

63. Cf. id. at 8-9 " "Groups with higher disability rates, of course, also experience more favorable treatment, ceteris paribus ...").

64. See Robert L. Bennefield \& John M. McNen, U.S. Dept. of Com., Labor force Status and Other Characteristics of Persons Wrth a Work Disabiltty: 1981 to 1988, at 5 tbl. E (U.S. Bureau of the Census, Current Population Rep., Series P.23, No. 160, 1989).

65. See id. at 13-14 tbl. 2 (showing for years between 1981 and 1988 women almost always reporting a lower incidence of severe disability than men within age groups). See also Leimer, supra note 59, at 9 (finding in study of years 1957 to 1995 that "males have generally experienced higher disability incidence rates within specific age groups than females, although the relationship within each age group has narrowed and expanded over time"). 
worker beneficiaries that year. ${ }^{66}$ These figures appear to be fairly representative of the years between 1957 and $1995^{67}$ and thus suggest that based on the likelihood of receiving benefits, women are relatively disadvantaged by Social Security's disability benefit provisions.

Although women generally are less likely to collect disability benefits than are men, there is some evidence to suggest that black women may be more likely to collect such benefits than are black men. In 1986, black women in most age groups were more likely to report a work disability than were black men. ${ }^{68}$ Similarly, black women in older age groups tended to report higher incidences of work disability than black men for the years 1981 through $1988 . .^{69}$ These higher disability incidence rates suggest that black women are more likely to collect disability benefits than are black men. In fact, black women do appear somewhat more likely to collect Social Security disability benefits than black men. Specifically, while $17.8 \%$ of all disabled worker beneficiaries were black in $1997,19 \%$ of disabled women worker beneficiaries were black and only $16.8 \%$ of disabled men worker beneficiaries were black. ${ }^{70}$

On the other hand, it is not clear how significant the differential in disability incidence between black men and women is. Although older black women were more likely than older black men to report work disa-

66. In 1997 , women represented $23,648,000$ or $58 \%$ of the total $40,904,000$ adult Social Security beneficiaries, $13,158,000$ or $48 \%$ of the total $27,275,000$ retired worker beneficiaries, and $1,842,000$ or $41 \%$ of the total $4,508,000$ disabled worker beneficiaries. See Social SECURTTY ADMIN., 1998 annual Statistical Supplement to the Social Security Bulletin 202 tbl. 5.A16 (1998) [hereinafter 1998 ANNUAL StatistiCal SUPPLEMENT].

67. See Leimer, supra note 59 , at 16 n. 35

The estimated ratio of DI disabled worker beneficiaries to OASDI taxpayers, a measure closely related to the DI disability rate, was substantially higher for males than females in each analysis year. The estimated ratio of DI disabled worker beneficiaries to OASDI taxpayers was also examined within generally 5-year age groups in the decennial years from 1960 through 1990; in each year examined, the ratio was higher for males than females within each age group.

See also U.S. Gen. Acct. Off., Social. Security Disability: Demographic and Economic CharacTERISTICS OF NEW BENEFICIARIES 12 (GAO/HRD-88-35BR Jan. 1988) (finding that the majority of disabled workers who came on to Social Security disability rolls between July 1980 and June 1981 were male and, that compared with the general population, a significantly higher proportion of disabled beneficiaries were male) [hereinafter NEW BENEFICIARIES].

68. See Monroe Berkowitz \& M. Anne Hill, Disability and the Labor Market: An Overview, in Disability and the labor Market: Economic Problems. Policies, and Programs 1, 10 (Monroe Berkowitz \& M. Anne Hill eds., 2d ed. 1989).

69. See BENNEFiELD \& MCNEIL, supra note 64, at 18-19 tbl. 2.

70. See 1998 AnNual Statistical SUPPLEMENT, supra note 66, at 184 \& 186 tbl. 5.Al (showing that while blacks represented $17.8 \%(800,940 / 4,505,760)$ of disabled worker beneficiaries, black women represented $19 \%(351,250 / 1,835,260)$ of total women disabled worker beneficiaries and black men constituted $16.8 \%(449,690 / 2,670,500)$ of total men disabled worker beneficiaries). 
bilities from 1981 through 1988, the reverse was true in younger age groups. ${ }^{71}$ Moreover, while black women are more likely to collect disability benefits than are black men, black women are also more likely to collect retired worker benefits. While $8 \%$ of all retired worker beneficiaries in 1997 were black, $8.5 \%$ of women retired worker beneficiaries were black and only $7.5 \%$ of men retired worker beneficiaries were black. ${ }^{72}$ Thus, there is some evidence to suggest that black women may be more likely to collect disability benefits than black men, but it is not unassailable. Based on the likelihood of receiving benefits, black women may, or may not, be relatively advantaged by Social Security's disability benefit provisions, while white women are clearly relatively disadvantaged.

\section{b. Minorities}

Blacks tend to become disabled more frequently than whites. For example, black men or women of any given age or level of schooling were more likely to report work disabilities in 1986 than were their white counterparts. ${ }^{73}$ This relationship remained relatively constant for the years between 1981 and 1988, and thus appears to represent a long term trend..$^{74}$

Because blacks are more likely to become disabled than whites, they should be more likely to collect Social Security disability benefits than whites. In fact, blacks do appear more likely to collect disability benefits. For example, while blacks represented $10 \%$ of Social Security beneficiaries in 1997, they comprised $18 \%$ of Social Security's disability beneficiaries that year. ${ }^{75}$ These figures have remained relatively constant over

71. See id.

72. See $i d$. at $184-186 \mathrm{tbl}$. 5.A1 (showing that while blacks represented $8 \%(2,181,470$ / $27,280,780)$ of total retired worker beneficiaries, black women represented $8.5 \%(1,124,240 /$ $13,154,740)$ of total women retired worker beneficiaries and black men constituted $7.5 \%(1,057,230$ / $14,126,040$ ) of total men retired worker beneficiaries).

73. See Berkowitz \& Hill, supra note 68, at 9-10.

74. See id. at 6,11-21 tbl. 1.2. See also AdvisORY COUNCL ON SOCIAL SECURTY, supra note 49, at 126 (showing similar higher incidence of severe disability for blacks based on 1972 survey data: "A 1972 survey of the disabled showed that $12.1 \%$ of black people aged 20 through 64 reported themselves severely disabled as compared to only $6.8 \%$ of the white population"); David L. Randall, Letter, Who's Subsidized?, Сн1. TrIB., Mar. 16, 1990, at 24, available in 1990 WL 2921039 (noting that "latest studies show that blacks make up a higher percentage of persons receiving [disability] benefits, relative to their numbers in the general population, than do whites").

75. There were $43,976,340$ OASDI beneficiaries in 1997 , of which $4,538,170$ or $10 \%$ were black; in contrast, blacks comprised $1,149,140$ or $18 \%$ of the $6,155,590$ DI beneficiaries that year. See 1998 Annual Statistical Supplement, supra note 66, at 183 tbl. 5.A1. 
the years ${ }^{76}$ and thus suggest that based on the likelihood of receiving benefits, blacks disproportionately benefit from Social Security disability provisions.

Although information on minority groups other than blacks is less complete, there is evidence to suggest that disability benefits may also accrue disproportionately to other minority groups. Hispanics report total work disabilities at about the same rate as whites. ${ }^{77}$ This fact suggests that Hispanics may be no more likely to collect disability benefits than whites. Hispanics, however, report severe disabilities at a higher rate than whites. ${ }^{78}$ Since severe work disabilities generally prohibit individuals from currently working, while individuals with disabilities that are not classified as severe may only have been prohibited from working in the past or be limited in their current employment, ${ }^{79}$ Hispanics in any given year may in fact be more likely to collect Social Security disability benefits than whites. ${ }^{80}$ Unfortunately, the Social Security Administration does not currently provide data on beneficiaries by Hispanic origin, ${ }^{81}$ and thus this hypothesis cannot be tested.

76. See, e.g., Advisory COUNCIL ON SOCIAL SECURITY, supra note 49, at 129

While blacks constitute $11.6 \%$ of the U.S. population and $10.3 \%$ of all social security beneficiaries, they represent only $7.8 \%$ of retired workers. On the other hand, blacks constitute $16.5 \%$ of disabled workers and dependents, $20.8 \%$ of children of retired and deceased workers, and $20.1 \%$ of the widowed mothers and fathers of young children receiving social security benefits.

See also Social SeCURITY AdMin., supra note 44, at 3 ("In 1996, 13\% of the general US population was African American. However, $25 \%$ of surviving children and $18 \%$ of disabled worker benefits were awarded to African Americans."); Driessen, supra note 35, at 90, 92

It is clear from incontrovertible statistics that Blacks of both sexes are disabled and/or die much earlier and at a higher rate than whites. . . Blacks comprise a disproportionate share of disability and survivors' beneficiaries, if we compare these proportions to the total black population or to the black Social Security population.

77. See BENNEFIELD \& MCNeIl, supra note 64, at 6, 11-21 tbl. 1 \& 2.

78. See id. See also Bureau of the Census, U.S. Dept. of Com., Census Brief No. 97-5. Dis. ABIIITIES AFFECT ONE-FIFTH OF ALL AMERICANS (1997) (noting that within the 55 to 64 year old group, $20 \%$ of whites had a severe disability versus $28 \%$ of Hispanics) [hereinafter CENSUS BRIEF 97-5].

79. See id., at 65 (defining work disability and severe work disability).

80. Relying on 1993 census data, Jerry Mashaw and Virginia Reno also found that Hispanics (and African-Americans) were more likely to report severe work disabilities than nonminorities. See Jerry L. Mashaw \& Virginia P. Reno, Overview, in Disabllity. WORK and CASH BenefrTs 1, 8 (Jerry L. Mashaw et al. eds., 1996) ("Severe work disabilities, which generally means the persons are prevented from working by their condition, were reported for $10 \%$ of African-Americans, $6 \%$ of Hispanics, and 5\% of whites.").

81. For a discussion of the race and ethnic classifications that the Social Security Administration has used over the years, see Leimer, supra note 59, at 4. 
The Social Security Administration does, however, provide beneficiary data on races classified as "other" than black or white. It defines "other" races as Asians, Pacific Islanders, American Indians and Alaskan Natives, and a subset of the total number of beneficiaries of Spanish origin. ${ }^{82}$ In 1997 , while races other than white or black comprised $3 \%$ of the total Social Security beneficiaries, ${ }^{83}$ they comprised $7 \%$ of the disability benefit beneficiaries. ${ }^{84}$ This suggests that minority groups other than blacks are also more likely to receive disability benefits than are whites; thus, based on likelihood of receipt of benefits, all minorities disproportionately benefit from Social Security's disability benefit provisions. ${ }^{85}$

Dean Leimer recently completed a study on redistribution under Social Security's disability provisions that confirms that disability benefits tend to favor minorities. ${ }^{86}$ Acknowledging and working within the inconsistencies and limitations of the Social Security Administration's data collection on race and ethnic variables, ${ }^{87}$ Leimer found that between the years of 1957 and 1995 the. Social Security disability insurance program had redistributed income within cohorts from whites to nonwhites. ${ }^{88}$ Specifically, he found that nonwhite males had the highest accumulated benefit/tax ratio, followed by nonwhite females. ${ }^{89}$

82. See 1998 Annual Statistical Supplement, supra note 66, at 193 n.4.

83. In 1997 , there were $43,976,340$ OASDI beneficiaries, of which $37,939,460$ or $86 \%$ were white, $4,538,170$ or $10 \%$ were black, and $1,293,550$ were other. See id. at 183 . For a definition of the "other" classification, see id. at 193 n. 4.

84. In 1997 , there were $6,155,590$ DI beneficiaries, of which $4,514,240$ or $74 \%$ were white, $1,149,140$ or $10 \%$ were black, and 428,650 or $7 \%$ were other. See id. For a definition of the "other" classification, see id. 193 n.4.

85. Similarly, Dean Leimer found that "[t]he estimated ratio of DI disabled worker beneficiaries to OASDI taxpayers, a measure closely related to the DI disability rate, was higher for Nonwhites than Whites in each analysis year [between 1957 and 1995] except the first, 1957." Leimer, supra note 59, at 15-16 n.32. While this data includes blacks, it provides some evidence that all minorities have consistently disproportionately benefitted from Social Security's disability benefit provisions. See also AARON, supra note 35 , at 80 (contending that disability and survivor insurance benefits disproportionately accrue to nonwhites); KINGSON \& BERKOwITZ, supra note 26, at 125 (declaring that minorities are more likely to receive disability and survivors' benefits).

86. See generally Leimer, supra note 59. The study was based on the Social Security's Administration's 1-Percent Continuous Work History Sample.

87. See id. at 4.

88. See id. Mr. Leimer recognized that minorities' lower life expectancies could have an adverse impact on their ability to collect disability benefits but found that "[o]n balance, . . . differences in such factors as earnings levels, disability rates, and dependent beneficiary relationships appear to work in favor of Nonwhites relative to Whites under the Dl program and also appear collectively to outweigh any opposing effect associated with differences in survivor probabilities." Id. at 9.

89. See id. at 10. He also found that white females had a higher documented benefittax ratio 


\section{c. Lower-Wage Workers}

Determining the relationship between wages and the likelihood of receiving Social Security disability benefits creates complexities that are not present with the other at-risk groups. By definition, ${ }^{90}$ recipients of Social Security's disability benefits should be totally disabled and thus earn no wages. ${ }^{91}$ Moreover, disabled workers tend to have lower incomes than nondisabled workers. ${ }^{92}$ Without addressing these complexities or trying to determine causality, ${ }^{93}$ it appears that lower-wage workers are more likely to receive Social Security disability benefits than are higher-wage workers. ${ }^{94}$

First, just as socioeconomic status is inversely related to life expec-

than that of white men, but neither of these ratios were as high as that of minorities.

90. The Social Security Act defines "disability" as an "inability to engage in any substantial gainful activity by reason of any ... physical or mental impairment which can be expected to result in death or which has lasted or can be expected to last for a continuous period of not less than 12 months." 42 U.S.C. § 423(d)(1)(A) (Supp. 1999).

In fact, Social Security disability beneficiaries may be permitted to earn wages during a trial work period as an incentive to return to work. See 42 U.S.C. § 422(c) \& 423(e)(1) (Supp 1999). See generally Cynthia M. Fagnoni, U.S. Acct. OfF., Social SecurtTy Disabllity: Multiple Factors AFFeCt RETURN to WoRK 9-11 (GAO/T-HEHS-99-82 Mar. 1999) (statement of Cynthia M. Fagoni, Director Income Security Issues Health, Education, and Human Services Division) (discussing trial work period and its effectiveness of incentives to return to work); Walter Y. Oi, Employment and Benefits for People with Diverse Disabilities, in DisABnITY, WORK AND CASH BENEFITS, supra note 80 , at 103, 199 (describing trial work period and noting that only $10 \%$ of cohort who were awarded Social Security disability benefits reported doing any work).

91. Cf. Jonathan S. Leonard, Labor Supply Incentives and Disincentives for Disabled Persons, in Disabritty and the labor Market: Economic Problems, Policies, and Programs, supra note 68, at 64, 80 (noting that for purposes of his study, "[t]he major econometric problem is that a large proportion of the sample, the SSDI beneficiaries in particular, are out of the labor force and have no observable current wage").

92. See, e.g., BENNEFIELD \& MCNER, supra note 64, at 5-6 tbl. E ("A third major correlate of work disability status is income." Showing that as income to poverty ratio increases, the likelihood of reporting a work disability decreases.).

93. Possible causes include the greater incentive lower-wage workers have to apply for disability benefits because the progressive benefit formula replaces a higher percentage of their wages and the more physically demanding nature of their jobs. Cf. Leonard, supra note 91 (discussing studies on effect of disability benefits on labor supply; all studies find that such benefits reduce the labor supply but disagree on the magnitude of the decrease); How Does Social Security Benefit Low Wage Workers?, 2 (Apr. 1999) [hereinafter LOW WAGE WORKERS] ("Low wage earners may also be at greater risk of disability because of the physical and environmental hazards that they face on the job."); Berkowitz \& Hill, supra note 68, at 11 ("The same condition that may force a grade-schooleducated manual laborer to withdraw from the labor force may only be an inconvenience to a profes. sional person.").

- 94. See also Bakija \& Steuerle, supra note 60 , at 16 ("Although the evidence is limited, it seems that those with lower-paying jobs may be more likely than average to apply for and receive disability benefits."). 
tancy, ${ }^{95}$ socioeconomic status is inversely related to health generally: ${ }^{96}$ individuals with lower incomes are more likely to classify themselves ${ }^{97}$ as being in poor health than are those with higher incomes. ${ }^{98}$ This fact suggests that lower-income workers are more likely to collect Social Security disability benefits than are their higher-income counterparts.

Educational attainment is also strongly correlated with work disability status. For instance, in 1988, within every age group, individuals were less likely to report a severe work disability as their level of education increased. ${ }^{99}$ Moreover, individuals with less education are more likely to be newly entitled Social Security disability beneficiaries than are individuals with higher educations. ${ }^{100}$ Since income generally rises with educational attainment, ${ }^{101}$ this also suggests that lower-wage workers are more likely to receive Social Security's disability benefits than are their higherincome counterparts.

95. See discussion supra Part II.A.

96. See Erica Goode, Social Status Getting Attention as Key to Health, Lexington HeRAlDLEADER, June 1, 1999, at A1 (Studies show that risk for a wide variety of illnesses "varies with relative wealth or poverty. The higher the rung on the socioeconomic ladder, the lower the risk.").

97. "Self-assessed health is a broad indicator of health and well being, which incorporates a variety of physical, emotional, and personal components of health. Several studies have shown selfassessed health to be a valid and reliable indicator of a person's overall health status and a powerful predictor of mortality and changes in physical functioning." U.S. DEP'T OF HEALTH AND HUMAN SER. vices, Pub. No. 98-1232, Health, United States, 1998: Socioeconomic Status and Health CHARTBOOK 102 (citations omitted) [hereinafter Health CHARTBOOK].

98. See LOW WAGE WORKERS,, supra note 93, at 2 ("Workers with low wages report poorer health than other wage groups."). For example, in 1995 depending on race, ethnicity and sex, poor adults were four to seven times as likely to report their health status as fair or poor as high-income adults. See Health ChartbooK, supra note 97, at 6. See also id. at 102-03 (giving more detailed statistics).

99. Bennefield \& McNeil, supra note 64, Table 3, at 22 (1989). See also Mashaw \& Reno, Overview, supra note 80 , at 7-8 (finding similar relationship between age and educational attainment based on March 1993 census data).

100. See Bakija \& Steuerle, supra note 60 , at 17.18 (noting that "(i)n 1990 , only $17 \%$ of newly entitled SSDI beneficiaries had any education beyond high school, compared to $38 \%$ of the total U.S. population over 25"); New BENEFICIARIES, supra note 67, at 14 (using SSA's 1982 New Beneficiary Survey, finding that compared with general population, Social Security disability beneficiary population generally less educated and significantly higher percentage had not completed high school); 1998 GREEN BOOK, supra note 13, at 55 tbl. 1-31 (showing over many years that SSDI beneficiaries generally less educated than overall U.S. population).

101. See U.S. Dept. of Com., Bureau of the Census. Stat. Brief 95-17, how Much We EARN-FACTORS THAT MAKE A DIFFERENCE (1995) (showing that within every age group earnings for both men and women increase as education increases but that men also earn more than women of the same age with the same level of education in every case); U.S. DEPT. OF COM.. BUREAU OF THE Census. Stat. Brief 94-17. More Education Means Higher Career Earnings (1994) (showing that mean annual earnings steadily increase with level of education); HEALTH CHARTBOOK, supra note 97, at 146 fig. 6 (showing that within gender, race, and ethnic groups, earnings steadily increase with educational attainment). 
Recent Social Security Administration data also provides some support for the proposition that lower-income workers are more likely to receive disability benefits than are higher-income workers. Specifically, although retired and disabled workers are about equally likely to have benefits based on low average lifetime earnings, ${ }^{102}$ retired workers are much more likely to have benefits based on high average lifetime earnings than are disabled workers. ${ }^{103}$

Finally, an econometric study by Jonathan Leonard provides additional support for the proposition that lower-wage workers are more likely to receive Social Security disability benefits. ${ }^{104}$ Leonard found that as past wages reach the Social Security taxable wage base, the probability of being a disability beneficiary approximates zero. ${ }^{105}$ With respect to wages below the taxable wage base, the probability of becoming a beneficiary decreases as past wages increase. ${ }^{106}$ Thus, while not absolute, the evidence suggests that lower-income workers are more likely to collect disability benefits than are higher-income workers.

\section{Conclusion}

In sum, it appears that minorities and lower-income workers disproportionately benefit from Social Security's disability benefit provisions. Not only do members of these groups (with the exception of Asians) disproportionately benefit from the progressive benefit formula, but they are more likely to receive disability benefits in the first place. Social Security disability benefit provisions' treatment of women is more complex. Although women tend to benefit from the progressive benefit formula, they are generally less likely to receive the benefits than are men; although it is possible that black women may be more likely to receive the benefits than black men. ${ }^{107}$

102. In $1997,25.4 \%$ of retired workers had benefits based on PIAs of $\$ 500$ or less. 1998 AN. NUal Statistical Supplement, supra note 66 , at 213 tbl. $5 . \mathrm{Cl}$. While $24 \%$ of disabled workers had benefits based on PIAs that low. See id. at 220 tbl. 5.E1.

103. In $1997,48 \%$ of retired workers had benefits based on PIAs of $\$ 800$ or more, See id. at 213 tbl. $5 \mathrm{Cl}$. While only $37.4 \%$ of disabled workers had benefits based on PIAs that high. See id. Table 5.E1, at 220.

104. See Leonard, supra note 91.

105. See id. at 83.

106. See id.

As past wage reaches the ceiling on social security taxable earnings, the probability of being a beneficiary approximates zero. The elasticity of beneficiary status with respect to having wages that surpass the ceiling is-19.4. Below the ceiling, the probability of becoming a beneficiary drops by 1 percentage point with a $12 \%$ increase in the level of past monthly wages.

107. Dean Leimer's recent study of the Social Security disability benefit provisions suggests 


\section{Auxiliary Benefits}

Social Security also pays auxiliary benefits to the spouses, surviving spouses, and dependent children of retired, disabled, and deceased workers. ${ }^{108}$ Like disability benefits, two factors are relevant in determining the redistributive effect of these benefit provisions: (1) the progressive benefit formula on which the benefits are based; and (2) the likelihood of the benefits being collected.

Like all other Social Security benefits, these auxiliary benefits are based on a progressive benefit formula. Thus, all other things being equal, these benefits also tend to favor all three of the at-risk groups (except Asians) because members of all three groups tend to earn lower wages.

With respect to the likelihood of collection, this section shows that women are far more likely to collect spouse and surviving spouse benefits than are men. The section further shows that white women are more likely to collect spouse benefits than are black women, while white and black women appear equally likely to collect surviving spouse benefits. Wives and widows of higher-income workers, on the other hand, appear more likely to collect spouse and surviving spouse benefits than the wives and widows of lower-income workers. With respect to dependent child benefits, nonwhite children are more likely to collect those benefits than are white children. The children of higher-income workers, however, may be somewhat more likely to collect the benefits than those of lowerincome workers. Given these conflicting trends, it is unclear how effective auxiliary benefits are in redistributing income. ${ }^{109}$

that the effect of the progressive benefit formula outweighs the effect of the likelihood of receiving benefits. Specifically, he found that nonwhite males had the highest accumulated benefit ratio followed by nonwhite females followed by white females followed by white males. Leimer, supra note 86 , at 10.

108. See infra Appendix Part B. Social Security's auxiliary benefits also include benefits to eligible widowed mothers and fathers, disabled widows and widowers, and dependent parents. This section, however, will not address those benefits because they only represent a very small percentage of Social Security beneficiaries. Specifically, of the $43,976,340$ Social Security beneficiaries in 1997 , only 229,890 were widowed mothers and fathers, 187,220 were disabled widows and widowers, and 3,540 were dependent parents. See 1998 ANNUAL StatistiCal SUPPLEMENT, supra note 66, at 183-93 tbl. 5A.1. In contrast, 3,134,130 of the beneficiaries were spouses, 3,778,780 were children, and 4,855,810 were nondisabled widows and widowers. See id. But see Driessen, supra note 35, at 95 (questioning significance of dependent child (and disability) benefits because they constitute a relatively small portion of the total Social Security wealth).

109. Cf. Marilyn R. Flowers \& John B. Horowitz, Distributional Implications of Social Security Spouse Benefit, 60 S. Eco. J. 490 (1993) (contending that current spouse benefits are slightly progressive). 


\section{Spouse and Surviving Spouse Benefits}

Spouse and surviving spouse benefits are facially gender-neutral. Women, however, are far more likely to receive those benefits than are men. For example, $99 \%$ of the beneficiaries who received Social Security benefits as spouses of retired workers in 1997 were women, ${ }^{110}$ and $98 \%$ of the beneficiaries who received Social Security benefits as spouses of disabled workers that year were women. ${ }^{11}$ Similarly, in 1997, 99\% of the beneficiaries who received benefits as nondisabled surviving spouses were women. ${ }^{112}$

Spouse and surviving spouse benefits, however, are not equally distributed among all women. ${ }^{113}$ For example, the benefits are not available to women who have never married. ${ }^{114}$ Nor are they available to divorced women if they were married for less than 10 years or have remarried.115 Similarly, surviving spouse benefits are not available until the beneficiary's spouse dies. ${ }^{16}$ Most importantly, Social Security's "dual entitlement

110. See 1998 AnNual Statistical Supplement, supra note 66, at 187-188 tbl. 5.Al (stating that of the $2,926,840$ beneficiaries who received benefits as spouses of retired workers, $2,897,260$ or $99 \%$ were wives while 29,580 or $1 \%$ were husbands).

111. See id. (stating that of the 207,290 beneficiaries who received benefits as spouses of disabled workers, 202,600 or $98 \%$ were wives while 4,670 or $2 \%$ were husbands).

112. See id. at 192-193 tbl. S.Al (stating that of the 4,855,810 beneficiaries who received benefits as nondisabled widows or widowers, $4,819,240$ or $99 \%$ were widows and only 36,570 or $1 \%$ were widowers).

113. Under the "worker-account" approach, spouse and surviving spouse are allocated to the age, race, and gender group of the worker on whose behalf the benefits were awarded. The "individual-specific" approach, in contrast, allocates those benefits to the age, race, and gender group of the auxiliary beneficiary. See Leimer, supra note 59 , at 4 . Although each has its advantages in determining the program's redistributive effects, this section will apply the individual-specific approach.

114. According to a census bureau special study, almost without exception black and Hispanic women of every age group are less likely to have ever married than are their white counterparts. See arthur J. Norton \& Louisa Miller, U.S. Dep't of Com. Current Population Rep. P23-180, MarRIAGE, DivorCe, AND RemarRiage IN THE 1990's 3 tbl. B (1990) (providing data for years 1975, 1980,1985 , and 1990). This fact suggests that black and Hispanic women may be less likely to receive Social Security benefits as spouses and/or surviving spouses than are white women. See id. However, the significance of this differential is not clear since less than $10 \%$ of all women, whether white, black, or of Hispanic origin between the ages of 50 and 54 have never married. See id.

115. Although black women are more likely than white women to divorce, black women are likely to take longer to divorce than are white women. See ReYNolds Farley \& SUzANNE M. BIanchi, Univ. of Mich., Res. Rep. No. 87-107. The Growing Racial. Difference in MarRiage and Family PatTerns 2 (1987). Thus, it is not clear how the higher divorce rate of black women is likely to effect their receipt of spouse and surviving spouse benefits as divorcees. For a more detailed discussion of divorced spouse beneficiaries, see Weaver, supra note 12.

116. The fact that blacks and lower income workers have lower life expectancies suggest that they are more likely to benefit from surviving spouse benefits than are whites and higher income workers. See supra notes $49-51$ and accompanying text. On the other hand, their surviving spouses may also have lower life expectancies which may offset the effect of the husbands' lower life 
rules" prevent individuals from collecting in full both worker benefits and spouse or surviving spouse benefits. ${ }^{117}$ Rather, individuals may only receive spouse or surviving spouse benefits to the extent that those benefits exceed their own workers' benefits. ${ }^{118}$

These dual entitlement rules may cause families with equal wages and equal payroll contributions to receive substantially different benefits, depending on whether the wages were earned by a single spouse or both spouses were wage earners. ${ }^{119}$ Generally, a wife can only expect to receive a spouse benefit if her lifetime earnings are less than about $30 \%$ of her husband's lifetime earnings. ${ }^{120}$ Overall, the rules tend to favor singleearner couples and disfavor couples in which both spouses contribute equally or almost equally to family income.

Unfortunately, there is not a great deal of information about wives' lifetime earnings relative to their husbands. ${ }^{121}$ There is some evidence, however, to suggest that the dual entitlement rules may favor whites over blacks. For example, according to statistics compiled by Dorothy Brown, the spouses in a black married household are more likely to contribute equally or almost equally to household income than are the spouses in a white married household. ${ }^{122}$ Similarly, Howard Iams found that black wives in the 1940s and 1950s were significantly less likely than white wives to earn substantially less than their husbands ${ }^{123}$ in his recent study

expectancies.

117. See infra Appendix B.

118. See id.

119. For a more detailed explanation and illustrations of how single-earner couples often receive larger benefits than dual-earner couples with identical lifetime earnings, see, for example, U.S. Gen. Acc. Off., Social Securtty: Issues Involving Beneft Equity for Working Women 15-21 (GAO/HEHS-96-55 Apr. 1996) [hereinafter WORKING WOMEN]; Karen C. Burke \& Grayson M.P. McCouch, Women, Fairness, and Social Security, 82 IowA L. REv. 1209, 1226 (1997); Forman, supra note 35 , at $944-46$.

120. See Howard M. Iams, Earnings of Couples: A Cohort Analysis, Soc. SECURITY BuLL, vol. 56 no. 3 , at 22,31 n.3 (1993).

121. See id. at 23

For the most part, we do not know how the accumulated work experience and earnings of wives relative to their husbands vary over time and across age groups. This is the case because most data measure experience at one point in time, or do not have large enough sample sizes to make reliable estimates by birth cohort. But in addition, the common research approach compares the eamings of women with those of men rather than comparing the earnings of wives with those of their husbands.

122. See Brown, supra note 54 , at $\mathbf{1 5 0 2 .}$

123. This relationship, however, did not hold true for all birth cohorts and being of Hispanic origin was not significant in determining the relationship between wives' earning and those of their own husbands. See id. 
of wives' earnings relative to their own husbands. ${ }^{124}$ These studies suggests that white spouses are more likely to collect spouse and surviving spouse benefits than are blacks. ${ }^{125}$

Recent Social Security Administration data confirms that white women are relatively more likely to collect spouse benefits than are black women. ${ }^{126}$ While white women represented $89 \%$ of the women retired worker beneficiaries in $1997,{ }^{127}$ they represented $92 \%$ of the wives of retired worker beneficiaries that year. ${ }^{128}$ Black women, in contrast, constituted $8.5 \%$ of the women retired worker beneficiaries, ${ }^{129}$ but only $5 \%$ of the wives of retired worker beneficiaries that year. ${ }^{130}$ Similarly, while $73 \%$ of the women disabled worker beneficiaries in 1997 were white, ${ }^{131}$ $77 \%$ of the wives of disabled worker beneficiaries were white. ${ }^{132}$ Conversely, while $19 \%$ of the women disabled worker beneficiaries in 1997 were black, ${ }^{133}$ only $14 \%$ of the wives of disabled worker beneficiaries were black. ${ }^{134}$

Unlike spouse benefits, white and black women appear equally likely to collect surviving spouse benefits based on recent Social Security Administration data. In 1997, white women constituted $89 \%$ of the women retired worker beneficiaries ${ }^{135}$ and $89 \%$ of the nondisabled widow

124. See lams, supra note 120 , at 29 . Overall, lams found that the likelihood of a wife having low earnings relative to her husband was related significantly to years of education, years of marriage, number of children, and husband's accumulated earnings level. Wives who were better educated were significantly less likely to have low earnings relative to their husbands while wives with more years of marriage, more children, and husbands with higher earnings were significantly more likely to have low earnings relative to their husbands. See id.

125. A recent study that found that white wives are more likely to drop out of the workforce for a longer period of time to care for children than are black wives also suggests that white women are more likely to benefit from spouse and surviving spouse benefits than are black women. See Howard M. lams \& Steven H. Sandell, Changing Social Security Benefits to Reflect Child-Care Years: A Policy Proposal Whose Time Has Passed?, Soc. SeCURITY BuLl., vol. 57, no. 4, 10 (Winter 1994).

126. 1998 annual Statistical Supplement, supra note 66, at 184 tbl. 5.A1.

127. See id. at $184(11,736,660$ of the $13,154,740$ women retired beneficiaries were white).

128. See id. at $187(2,675,620$ of the $2,897,260$ wives of retired worker beneficiaries were white).

129. See id. at $184(1,124,240$ of the $13,154,740$ women retired beneficiaries were black).

130. See id. at $187(145,300$ of the $2,897,260$ wives of retired worker beneficiaries were black).

131. See 1998 Annual Statistical Supplement, supra note 66 , at $186(1,346,210$ of the $1,835,260$ disabled women beneficiaries were white).

132. See id. at 188 ( 156,360 of the 202,620 wives of disabled worker beneficiaries were white).

133. See id. at 186 ( 351,250 of the $1,835,260$ disabled women beneficiaries were black).

134. See id. at 188 (28,600 of the 202,620 wives of disabled worker beneficiaries were black).

135. See id. at 184 (11,736,660 of the $13,154,740$ women retired beneficiaries were whites). 
beneficiaries. ${ }^{136}$ Similarly, black women represented $8.5 \%$ of the women retired worker beneficiaries ${ }^{137}$ as well as $8.4 \%$ of the nondisabled widow beneficiaries. ${ }^{138}$

Women of other races ${ }^{139}$ are about as likely to collect retired worker benefits as they are to collect benefits as the wives of retired workers or as nondisabled widow beneficiaries based on recent Social Security Administration data. Women of other races, however, are somewhat more likely to collect benefits as the wives of disabled workers than they are as disabled workers themselves. Specifically, in 1997, women of other races represented about $2 \%$ of the women retired worker beneficiaries, ${ }^{140}$ as well as about $2 \%$ of the wives of retired worker beneficiaries ${ }^{141}$ and $2 \%$ of the nondisabled widow beneficiaries. ${ }^{142}$ In contrast, $6.5 \%$ of the women disabled worker beneficiaries were of other races, ${ }^{143}$ while $8 \%$ of the wives of disabled workers were women of other races. ${ }^{144}$

Wives and widows of higher-income workers appear more likely to collect Social Security's spouse and surviving spouse benefits, based on recent Social Security Administration data. At the end of 1997, almost $75 \%$ of the spouses of retired workers had benefits based on high average lifetime earnings ${ }^{145}$ as did almost $60 \%$ of nondisabled surviving spouses. $^{146}$ In contrast, fewer than one-half of retired workers had bene-

136. See 1998 Annual Statistical Supplement, supra note 66, at $192(4,314,790$ of the $4,819,240$ nondisabled widow beneficiaries were white).

137. See id. at $184(1,124,240$ of the $13,154,740$ women retired workers beneficiaries were black).

138. See id. at 192 (413,740 of the $4,819,240$ nondisabled widow beneficiaries were black).

139. For a definition of other races, see supra note 82.

140. See 1998 ANNuAl Statistical SUPPLEMENT, supra note 66, at 184 tbl. 5.Al (249,110 of the $13,154,740$ women retired beneficiaries were of other races).

141. See id. at $187(66,260$ of the $2,897,260$ wives of retired worker beneficiaries were of other races).

142. See id. at $192(78,560$ of the $4,819,240$ nondisabled widow beneficiaries were of other races). races).

143. See id. $186(120,880$ of the $1,835,260$ women disabled worker beneficiaries were other

144. See id. at $188(15,890$ of the 202,620 wives of disabled worker beneficiaries were of other races).

145. See 1988 Annual Statistical Supplement, supra note 66, at 213 tbl. 5. Cl (benefits based on PIAs of $\$ 800$ or more). Similarly, less than $10 \%$ of spouses of retired workers had benefits based on PIAs of less than $\$ 500$ while more than $25 \%$ of retired workers had benefits based on PIAs this low. See id. For a discussion of PIAs and how they are calculated. See supra Appendix Part B.

146. See 1998 Annual \& Statistical Supplement, supra note 66, at 225 tbl. $5 . F 7$ (benefits based on PIAs of $\$ 800$ or more). Similarly, just over $11 \%$ of nondisabled surviving spouses had benefits based on PIAs of less than $\$ 500$, id., while more than $25 \%$ of retired workers had benefits based on PIAs this low. See id. at 213 tbl. 5.C1. 
fits based on high average lifetime earnings. ${ }^{147}$ Likewise, almost $55 \%$ of spouses of disabled workers had benefits based on high average lifetime earnings, while less than $38 \%$ of disabled workers had benefits based on high lifetime earnings. ${ }^{148}$ In addition to the Social Security Administration data, Iams' study also indicates that the wives of higher-wage workers are more likely to collect these benefits than are the wives of lowerwage workers, because the wives of higher-wage workers are significantly more likely to earn substantially less than their husbands. ${ }^{149}$

\section{Dependent Child Benefits}

Blacks and other races appear more likely to receive Social Security's dependent child benefits than whites. While blacks only represented $10 \%$ of the total Social Security beneficiaries in 1997, ${ }^{150}$ they constituted $23 \%$ of the dependent child beneficiaries that same year. ${ }^{151}$ Similarly, while $3 \%$ of the Social Security beneficiaries were individuals of other races in 1997,152 about $7 \%$ of the dependent child beneficiaries were of other races. ${ }^{153}$ In contrast, whites represented $86 \%$ of the total Social Security beneficiaries, ${ }^{154}$ but only $69 \%$ of the dependent child beneficiaries. ${ }^{155}$

The children of higher-income workers may be somewhat more likely to receive dependent child benefits than the children of lowerincome workers, based on recent Social Security Administration data. ${ }^{156}$

147. See id. at 213 tbl. $5 . \mathrm{Cl}$ (based on PIAs of $\$ 800$ or more). The average PIA for retired workers was $\$ 772$ while the average PIA for spouses of retired workers was $\$ 964$. See id.

148. See id. at 220 tbl. $5 . E 1$ (based on PIAs of $\$ 800$ or more). Similarly, about $8 \%$ of spouses of retired workers had benefits based on PIAs of less than $\$ 500$ while $24 \%$ of retired workers had benefits based on PIAs this low. See id. The average PIA for disabled workers was $\$ 728$ while the average PIA for spouses of disabled workers was $\$ 860$. See id.

149. See lams, supra note 120 , at 29 . To the extent that the wives are better educated, however, they may be less likely to receive those benefits. $C f$. id. (finding that better educated women are significantly less likely to have low earnings relative to their husbands).

150. See 1998 ANNUAL STATISTICAL SUPPLEMENT, supra note 66 , at $183(4,538,170$ or $10 \%$ of the $43,976,340$ Social Security beneficiaries were black in 1997).

151. See id. at 189 ( 869,880 or $23 \%$ of the $3,778,780$ child beneficiaries were black).

152. See id. $183(1,293,550$ or $3 \%$ of the $43,976,340$ Social Security beneficiaries were of other races).

153. See id. at 213 tbl. $5 . \mathrm{Cl}(257,860$ or $7 \%$ of the $3,778,780$ child beneficiaries were of other races).

154. See id. at $183(37,939,460$ or $86 \%$ of the $43,976,340$ Social Security beneficiaries were white).

155. See 1988 Annual Statistical Supplement, supra note 66, at 189 (showing that $2,602,020$ or $69 \%$ of the $3,778,780$ child beneficiaries were white).

156. See id. at 213 tbl. 5.C1, 220 tbl. 5.E1, 225 tbl. 5.F7. 
Specifically, at the end of 1997 , the children of retired workers were more likely to have benefits based on high average lifetime earnings than were retired workers, ${ }^{157}$ and were less likely to have benefits based on low average lifetime earnings than were retired workers ${ }^{158}$ or disabled workers. ${ }^{159}$ On the other hand, the evidence is not unequivocal. The children of disabled workers were about as likely to have benefits based on high lifetime earnings as were disabled workers, ${ }^{160}$ and surviving child beneficiaries were less likely to have benefits based on high average lifetime earnings than were retired workers. ${ }^{161}$ Likewise, surviving child beneficiaries were about as likely as retired workers to have benefits based on low average lifetime earnings. ${ }^{162}$ Thus, the children of higher-income workers may be somewhat more likely to receive dependent child benefits than the children of lower-income workers, but this does not appear to be true in all instances.

\section{Conclusion}

There is little doubt that Social Security's spouse and surviving spouse benefits have effectively transferred income within cohorts from single earners to married couples, and particularly to married couples with one earner. ${ }^{163}$ In addition, there is little doubt that women are far more likely to collect those benefits than are men.

The distribution of spouse and surviving spouse benefits among women is less clear. Nevertheless, it appears that white women are more

157. Almost $59 \%$ of the children of retired workers had benefits based on PIAs of $\$ 800$ or more while $48 \%$ of retired workers had benefits based on PIAs that high. See id. The average PIA for retired workers was $\$ 772$ while the average PIA for children of retired workers was $\$ 856$. See id.

158. Just under $15 \%$ of children of retired workers had benefits based on PIAs of less than $\$ 500$ while over $25 \%$ of retired workers had benefits based on PIAs that low. See id.

159. Less than $13 \%$ of children of disabled workers had benefits based on PIAs of less than $\$ 500$ while $24 \%$ of disabled workers had benefits based on PIAs that low. See 1988 ANNUAL. STATISnCAL SUPPLEMENT, supra note 66, at 220 tbl. 5.El. The average PIA for disabled workers was $\$ 728$ while the average PIA for children of disabled workers was $\$ 770$. See id.

160. About $39 \%$ of children of disabled workers had benefits based on PIAs of $\$ 800$ or more, while more than $37 \%$ of disabled workers had benefits based on PIAs that high. See id. at 220 tbl. 5.E1, 225 tbl. 5.F7.

161. Just under $40 \%$ of surviving child beneficiaries had benefits based on PIAs of $\$ 800$ or more, while $48 \%$ of retired workers had benefits based on PIAs that high. See id. at 213 tbl. 5.Cl.

162. Twenty-four percent of surviving child beneficiaries had benefits based on PIAs of $\$ 500$ or less, while just over $25 \%$ of retired workers had benefits based on PIAs that low. See id. at 213 tbl. 5.Cl, 225 tbl. 5.F7.

163. See authorities cited in Moore, supra note 14, at 973 n.24. Whether this is an appropriate redistributive policy is subject to considerable debate. See id. at $988 \mathrm{n} .81$ and authorities cited therein. 
likely to collect spouse benefits than are black women, while white and black women are equally likely to collect surviving spouse benefits. Women of other races are about as likely to collect retired worker benefits as they are to collect spouse or surviving spouse benefits, but they are somewhat more likely to collect benefits as the wives of disabled workers than they are to receive benefits as disabled workers themselves. The wives of higher-wage workers are more likely to receive spouse and surviving spouse benefits than are the wives of lower-wage workers.

Nonwhites disproportionately benefit from Social Security's dependent child benefits. On the other hand, the children of higher-income workers may be somewhat more likely to collect dependent child benefits than the children of lower-income workers, although the evidence is not indisputable.

\section{CONCLUSION}

Careful consideration of the four elements of the current Social Security System that are most relevant in determining how the program redistributes income: (1) the method by which benefits are paid out; (2) the progressive benefit formula; (3) disability benefits; and (4) auxiliary benefits, helps explain why commentators vigorously debate how effective Social Security has been in redistributing income within generations. Only one of the four factors, the progressive benefit formula, treats all three of the at-risk groups in the same manner. Moreover, there is even an exception with respect to that factor. The progressive benefit formula tends to benefit all three of the at-risk groups: women, minorities, and lower-income workers, with the exception of Asians. The way in which the other three elements affect the at-risk groups is mixed, and in some cases more complex.

Benefits are paid out by a method that clearly tends to favor women, Hispanics, and Asians and to disadvantage blacks and lower-income workers. The effect of the disability benefit provisions is dependent on two factors: (1) its progressive benefit formula; and (2) the likelihood of beneficiaries collecting such benefits. The progressive benefit formula tends to favor all three of the at-risk groups (with the exception of Asians), while the likelihood of collecting disability benefits varies among the at-risk groups. Minorities and lower-wage workers are more likely to receive disability benefits than are their non-minority and higher-wage counterparts. In contrast, women (with the possible exception of black women) are less likely to receive disability benefits than are men. Thus, Social Security's disability benefit provisions clearly tend to 
favor minorities (except perhaps Asians) and lower-wage workers, while its effect on women is mixed.

The effect of auxiliary benefits also depends on the same two factors: (1) the progressive benefit formula; and (2) the likelihood of collecting benefits. Again, the progressive benefit formula tends to benefit all three of the at-risk groups (with the exception of Asians), while the likelihood of collecting auxiliary benefits varies among the at-risk groups. Women are far more likely to collect spouse and surviving spouse benefits than are men, but it is more difficult to determine how the benefits are distributed among women. Overall, white women appear more likely to collect spouse benefits than black women, while white and black women appear equally likely to collect surviving spouse benefits. Wives and widows of higher-income workers, on the other hand, appear more likely to collect spouse and surviving spouse benefits than the wives and widows of lower-income workers. With respect to dependent child benefits, nonwhite children are more likely to collect those benefits than are white children. In contrast, the children of higher-income workers may be somewhat more likely to collect the benefits than those of lower-income workers.

While recognizing that determining how the current Social Security system redistributes income is complex, this Article lays an important foundation for evaluating proposed reforms of the system. Since one of the fundamental purposes underlying the current system is to lift the elderly out of poverty, policymakers can and should consider how reform would interact with the four factors discussed above in order to determine how reform would likely affect beneficiaries who are at a heightened risk of poverty in old age.

\section{APPENDIX}

Part A of this appendix briefly describes funding under the current Social Security system. Part B then describes benefits under the current system.

\section{A. Funding Under the Current Social Security System ${ }^{164}$}

Social Security is financed principally ${ }^{165}$ by "contributions," or pay-

164. For a more comprehensive discussion of the funding provisions, see MYERS, supra note 2 , at $129-43$.

165. Currently, the OASI program receives approximately ten percent of its income from other sources. Because the Social Security program is currently running a surplus, and that surplus is invested in special-issue Treasury securities, interest on those securities provides approximately $8.4 \%$ 
roll taxes imposed on employers and employees. The Federal Insurance Contributions Act $^{166}$ requires that employers ${ }^{167}$ and employees ${ }^{168}$ each "contribute" $6.2 \%$ of wages, ${ }^{169}$ up to a maximum taxable wage base, indexed for inflation and equal to $\$ 72,600$ in $1999,{ }^{170}$ to finance old-age survivor and disability insurance benefits. ${ }^{171}$ "Contributions" are mandatory; employers and employees can not opt out of the system. ${ }^{172}$

As originally enacted, Social Security provided for the creation of a substantial reserve ${ }^{173}$ to fund future Social Security benefits. ${ }^{174}$ The creation of such a reserve, however, was widely criticized. ${ }^{175}$ In 1939, Congress amended the program to increase benefits to the first generation of retirees $^{176}$ and to shift the program towards a pay-as-you-go system

of the OASI program income. In addition, a portion of Social Security benefits may be subject to federal income tax. Revenues from that tax are transferred into the Social Security trust fund and represent about $1.4 \%$ of the program's total income. See PANIS \& Lillard, supra note 50, at 4.

Although Social Security is usually a self-supporting system, the 1983 amendments to the Act directed that certain benefits be financed out of general revenues. See DIFFERENT APPROACHES, supra note 5 , at $37 \&$ n. 39 (describing benefits to be funded out of general revenues); MYERS, supra note 2, at 29-30 (noting this exception to general rule that Social Security is self-supporting system).

166. 26 U.S.C. $\S \S 3101-3128$ (1994). The self-employed are required to make similar "contributions." 26 U.S.C. $\$ \S 1401-1403$ (1994).

167. See 26 U.S.C. § 3111(a) (1994).

168. See 26 U.S.C. \& 3101(a).

169. $5.35 \%$ of the tax is allocated to the OASI program while $.85 \%$ is allocated to the DI program. Board of Trustees, supra n.9, at 6. For a table listing the tax rates from 1937 through 1998, see CCH, 1998 Social SeCuRtry Explained, I 201, at 29-30 (Health Law Prof'l Series 1998).

170. See 26 U.S.C. \& 3121(a)(1) (1994). For a table listing the taxable wage base for each year from 1937 through 1998, see CCH, supra note 169, 9 208, at 40. For 1999's rate, see Increases in Annual Contribution Rates and Exempt Earnings Amounts for 1999, Soc. SECURrry BULL, vol. 61, no. 3 , at 45,45 (1998).

171. The Act also requires that employers and employees contribute $1.45 \%$ of wages to fund hospital insurance, that is, Medicare. See 26 U.S.C. \$§ 3101(b), 3111(b) (1994).

172. For a discussion of the compulsory nature of the Social Security program, see Moore, supra note 1, at 136-137 and sources cited therein. See also KINGSON \& BERKOwrTZ, supra note 26, at 120-21 (discussing justifications for compulsory nature of Social Security).

173. The reserve was expected ultimately to reach $\$ 47$ billion. See Charles M. Brain, Social Security at the Crossroads 56 (1991); J. Douglas Brown, An American Phrosophy of Social SECURITY: EVOLUTION AND ISSUES 179 (1972).

174. The reserve was to have accumulated because payroll tax revenues in the early years of the system were expected to greatly exceed expenditures. See Martha Derthick. Brookings Inst., Polucymaking for SOCIAL SeCURIry 233 (1979). See generally Myers, supra note 2, at 375-78 (explaining why a reserve develops).

175. For citations to those criticisms, see Moore, supra note 1, at 139 n.54.

176. As a result of the amendment, the early retirees received far more than they paid into the system. See Alicia H. Munnell, Brookings Inst., The future of Social Security 128 (1977). See also Alan Pifer \& Forrest Chisman, Foreward to RePort of the CoMmitree on ECONOMIC SECURITY of 1935. and Other Basic Documents Relating the Social Security Act xi (50th Anniversary ed. 1985) ("In broad terms, the thrust of the 1939 Amendments was twofold. First, in place of a 
where current revenues were used to fund current benefits. ${ }^{177}$ From 1939 to 1977 , Social Security was financed principally on a pay-as-you-go basis. ${ }^{178}$ In 1977, and again in 1983, Congress amended Social Security to move away from the pay-as-you-go system toward a system with temporary partial-reserve financing where reserves are to be built up for a few decades and then used to pay for future benefits. ${ }^{179}$ Thus, under the current system, most current revenues are used to finance current benefits, but some current revenues are set aside to fund future benefits. ${ }^{180}$

\section{B. Benefits Under the Current Social Security System ${ }^{181}$}

Social Security pays two basic types of benefits to workers: (1) old-

large reserve account for old-age benefits, the adoption of a 'pay as you go system' with a partial reserve meant each generation would finance its parents' retirement out of current earnings.").

177. "A pay-as-you-go social security system is one in which annual revenues dedicated to the system approximately equal annual expenditures." AARON, supra note 35 , at 7 . For a discussion of the difference between the operation of a funded system and a pay-as-you-go system, see Carolyn L. Weaver. The Crisis in Social Security 119-21 (1982).

178. Technically, until 1972, financing was on a contingency-fund basis. In 1972, Social Security was amended to provide for financing on a pay-as-you-go basis. See MYERS, supra note 2, at 386, 388

The 1939 Act changed the financing basis to what was generally believed to be a pay-as-yougo basis or, more properly, a contingency-fund basis. . . The 1972 Act . . moved the financing basis for the future to current-cost (or pay-as-you-go) from the previous modifiedreserve procedure. It is important to note that, in the past decade, the actual experience had been close to current-cost financing. . . .

See also AARON, supra note 35, at 7 ("Although it accumulated a modest reserve in its early years and that reserve is now declining, the U.S. social security system is essentially a pay-as-you-go system.").

179. See generally 1994-1996 ADVISORY COUNCIL REPORT, supra note 4, at 16 ("As a result of the 1977 and 1983 Social Security Amendments, the Social Security Trust Funds began to accumulate some reserves . . . in advance of the sharply rising retirement costs of the baby boom generation."); Barry P. Bosworth, Fund Accumulation: How Much? How Managed?, in SOCIAL. SECURITY: What Role for the Future? 101 (Peter A. Diamond et al. eds., 1996) ("With the 1977 and 1983 Social Security amendments, Congress began to move away from a pay-as-you-go system of financing, toward a greater emphasis on the adjustment of taxes and promised benefit levels to maintain an actuarial balance between future costs and future income."); MYERS, supra note 2, at 390

The 1977 Act-perhaps unintentionally-changed the financing basis from pay-as-you-go to the hybrid one of temporary partial-reserve funding, by intending to build up a mammoth fund over a period of years and then liquidating it. . . The 1983 Act did not change the financing basis, but rather exacerbated it by producing even larger fund buildup in the next few decades."

For a detailed discussion of how the reserves developed, see Forrest P. Chisman, Social Security Reserves and the Budget Deficit, in SOCIAl SecurtTy and Economic Well-Being Across GeneranoNs 39, 39-59 (John R. Gist ed., 1988).

180. At present, approximately $\$ 500$ billion has been set aside to pay for future benefits. See 1994-1996 ADVISORY COUNCIL. REPORT, supra note 4, at 16.

181. For a comprehensive discussion of the benefit provisions, see MYERS, supra note 2, at 
age $^{182}$ and (2) disability ${ }^{183}$ benefits. In addition, it pays "auxiliary" 184 or "derivative" 185 benefits to certain family members of retired, disabled, and deceased workers. ${ }^{186}$ All of these benefits are based on the workers' earnings record. ${ }^{187}$

To calculate old-age benefits, the government begins by determining the number of years upon which to base benefits. ${ }^{188}$ The base is currently 35 years for everyone born after 1928 and retiring in 1991 or later. ${ }^{189}$ Earnings are then indexed for inflation. ${ }^{190}$ Average adjusted earnings, or "average indexed monthly earnings" ("AIME"), are then calculated by taking the best 35 years of earnings adjusted for past wage inflation, ${ }^{191}$ adding them together' and dividing by 420 (the number of months in 35 years). ${ }^{192}$ Average adjusted earnings ${ }^{193}$ are then multiplied by a progressive benefit formula to determine the "primary insurance amount" (PIA), or how much of the average adjusted earnings should be replaced. ${ }^{194}$ The formula replaces a higher percentage of adjusted average earnings the

47-129.

182. See 42 U.S.C. § 402(a) (1994).

183. See 42 U.S.C. § 423(a) (1994).

184. See MYERS, supra note 2, at 57-58 (referring to benefits received by family members of retired or disabled workers as auxiliary benefits); Forman, supra note 35, at 924-925 (referring to benefits; to dependents and survivors of workers as auxiliary benefits).

185. See Burke \& McCouch, supra note 119 , at 1214 (referring to benefits received by family members of retired, disabled, or deceased workers as "derivative" benefits).

186. See 42 U.S.C. § 402 (b)-(h) (1994).

187. The special minimum benefit is an exception to this rule. It is based on years of covered employment rather than earnings. See 42 U.S.C. § 415(a)(1)(A), (a)(1)(C) (1994). See also 1998 GREEN BOOK, supra note 13, at 25.

188. See Social Security Admin., Social Securtty: Understanding the Benefits 11 (1996) [hereinafter UNDERSTANDING THE BENEFTTS].

189. See id. at 11. For those born in 1928 or earlier, there are fewer years in the base. See id.

190. See 42 U.S.C. § 415(b) (1994). All individuals who reach 65 after 1983 must index their earnings. Individuals who reached age 62 before 1979 may not index their earnings, and individuals who reached age 62 after 1979 but before 1984 may, but are not required to, index their eamings. See 2A Social Security Law and Practice §§ 22:5-7 (1987).

To index earnings, "each year's wage is multiplied by an 'indexing factor,' which equals the ratio of the average national wage in the year the worker turns 60 to the average national wage in the year to be indexed. For administrative convenience, wages earned at age 60 or later are left at their nominal values in the indexing process."

STEUERLE \& BAKUA, supra note 35 , at 76.

191. For individuals born before 1928, fewer than 35 years will be taken into account. See UNDERSTANDING THE BENEFITS, supra note 188, at 11. See id.

192. Again, for individuals born in 1928 or earlier, fewer months will be taken into account.

193. For a discussion of the advantages of using average earnings, see J. Douglas Brown. EsSAYS ON SOCIAL SECURITY 21-23 (1977).

194. See 42 U.S.C. $\$ 415(\mathrm{a})$ (1994). 
lower one's average earnings so that the ratio of benefits to average earnings is higher for those with low average earnings than for those with high average earnings. For those reaching age 62 in 1999, the formula replaced $90 \%$ of the first $\$ 505$ of AIME, plus $32 \%$ of AIME between $\$ 505$ and $\$ 3,043$, plus $15 \%$ of AIME above $\$ 3,043 .{ }^{195}$ As a result of the application of this progressive benefit formula, Social Security benefits replace approximately $56 \%$ of the AIME of workers with low lifetime covered earnings, $42 \%$ of the AIME of workers with average lifetime covered earnings, and $29 \%$ of the AIME of workers with lifetime covered earnings at or above the maximum taxable level. ${ }^{196}$ Disability benefits are calculated in a similar manner, but fewer than 35 years may be taken into account in determining the PIA for a disabled worker. ${ }^{197}$

Under current law, a worker ${ }^{198}$ is entitled to receive "full benefits," that is, benefits equal to her PIA, at "Normal Retirement Age." 199 The normal retirement age is currently age 65 but is scheduled to increase gradually to age 67 by the year 2022.200 A worker may elect to receive actuarially reduced benefits as early as age $62 .{ }^{201}$ Similarly, a worker may elect to delay the receipt of benefits beyond age 65 and receive a less than actuarially fair increased benefit. ${ }^{202}$ A "totally disabled" 203

195. See Board of Trustees, Fed. Old-Age and Survivors Ins. ANd Disability Ins. Trust Funds, 1999 Annual Report 68 (1999) [hereinafter 1999 TRUSTEEs REPORT]. For a more detailed discussion on how to calculate Social Security benefits, see STEUERLE \& BAKUA, supra note 35, at 75 83. See also 1999 TRUSTEES' REPORT, at 64-69 (showing values for program amounts that are subject to automatic adjustment).

196. See DIFFerent APPROACHES, supra note 5, at 15.

197. For disabled workers, the PIA is calculated as though the worker had attained age 62 at the time of disablement. See 42 U.S.C. 423(a)(2) (1994). See also CCH, supra note 169, GD 507.3, 520.2; MYers, supra note 2, at 54; STEUERLE \& BAKUA, supra note 35, at 84-85.

198. In order to be eligible for old-age benefits, a worker must be "fully insured;" that is, the worker must have worked in covered employment for a long enough period of time. See 42 U.S.C. $\$ \S 402(a)(1), 414(a)(1994)$. For a discussion of the "fully insured" requirement, see CCH, supra note 169, 91 504-505; MYERS, supra note 2, at 47-49.

199. See MYERS, supra note 2, at 51 (noting this terminology could be used differently but contending that it makes sense to refer to age 65 as the normal retirement age and $100 \%$ of the PIA as full benefits). See also StEuERLE \& BAKIJA, supra note 35 , at 76 (using normal retirement age terminology).

200. The normal retirement age is scheduled to increase for workers born in 1938 and thereafter. For a table showing how the Normal Retirement Age will gradually increase, see CCH, supra note 169, I 518, at 204; MYERS, supra note 2, at 51.

201. See 42 U.S.C. $\S 402$ (q) (1994). Benefits are currently reduced by $5 / 9$ of $1 \%$ of the amount of the benefit, multiplied by the number of months in the period beginning with the first month for which the individual is entitled to the benefit and ending with the month before the month in which he or she would attain normal retirement age. See id. See also CCH, supra note 169. II 535.1, at 262.

202. See 42 U.S.C. $\$ 402(w)(1994)$. For a discussion of the calculation of the delayed retire- 
worker $^{204}$ is also entitled to receive benefits equal to her PIA. ${ }^{205}$

Upon reaching age 65,206 the spouse ${ }^{207}$ of a retired or disabled worker is entitled to receive a spouse benefit equal to $50 \%$ of the worker's PIA. ${ }^{208}$ The spouse may elect to receive an actuarially reduced benefit as early as age $62 .{ }^{209}$ Spouses who are entitled to receive benefits based upon their own earnings record as well as their spouse's earnings record may only receive a total benefit equal to the larger of the two benefits. ${ }^{210}$ Thus, those spouses whose worker benefits exceed their spouse benefits are only entitled to receive their own worker's benefit. In contrast, "dually entitled" beneficiaries, that is, spouses whose spouse benefits exceed their worker's benefits, ${ }^{211}$ are only entitled to a total benefit equal to their spouse benefit. ${ }^{212}$ A retired worker's dependent children $^{213}$ may also be eligible to receive a benefit equal to $50 \%$ of the

ment credit, see $\mathrm{CCH}$, supra note 169 , II 539. Although the delayed retirement credit is not currently actuarially fair, a modification of this credit has been phased in so that by 2009 the delayed retirement credit should be actuarially fair. See AdVISORY COUNCIL ON SOCIAL SECURITY, supra note 49, at 73 .

203. See 42 U.S.C. $\S 423(a)(D)$, (d) (1994). For a detailed discussion the "totally disabled" requirement, see $\mathrm{CCH}$, supra note 169 , If 520.1; MYERS, supra note 2, at 54-56.

204. In order to be eligible for benefits, a totally disabled worker must also be fully insured and "disability insured"; that is the worker who must have worked in covered employment long enough and recently enough. See 42 U.S.C. $\S 423(a)(1)(A)$, (c) (1994). For a detailed discussion of the "disability insured" requirement, see CCH, supra note 169, II 505.5; MYERS, supra note 2, at 50.

205. See note 197 . If the worker becomes disabled after having received early retirement benefits, the benefit will be actuarially reduced for the period of time during which the worker received early retirement benefits. See 42 U.S.C. § 402(q)(2); CCH, supra note 169, II 520.7; MYERS, supra note 2 , at $54 \&$ n. 44 .

206. Just like the Normal Retirement Age for old-age benefits, this age is scheduled to increase gradually to age 67. See supra note 200 and accompanying text. See also MYERS, supra note 2, at 51. A spouse, regardless of age, may also receive such a benefit if the spouse has care of a child under age 16 or a child of any age who was disabled prior to age 22 . See 42 U.S.C. $\S 402$ (b)(1)(B), (c)(1)(B) (1994); CCH, supra note 169, 9l 522, at 236; MYERS, supra note 2, at 57 58.

207. Divorced spouses may also be entitled to receive benefits. For a more detailed discussion of benefits for divorced spouses, see CCH, supra note 169, II 522.5; Cariton D. Stansbury, The Family Law Practitioner's Guide to Social Security, 1995 A.B.A. SEC. FAM. L. 37-39.

208. See 42 U.S.C. § 402(b)(2) (1994).

209. For a discussion of the actuarial reduction, see MYERS, supra note 2, at 59 . The benefit of a spouse caring for a minor or disabled child of the insured will not be actuarially reduced. See $\mathrm{CCH}$, supra note 169 , If 522 .

210. See Steurele \& Bakda, supra note 35 , at 80 .

211. See, e.g., 1998 AnNual Statistical SuPplement, supra note 66, at 231 tbl. 5.G2; STEUERLE \& BAKUA, supra note 35, at 80; Barbara A. Lingg, Women Beneficiaries Aged 62 or Older, 1960-88, 53 Soc. SeCurity Bull., vol. 53, no. 7, at 2 (1990).

212. See 42 U.S.C. $\S 402(k)(3)(A)(1994)$. See also $\mathrm{CCH}$, supra note 169, II 521, at 235; Burke \& McCouch, supra note 119 , at 1214 \& n.25.

213. See 42 U.S.C. $\S 402$ (d) (1994). For a more detailed discussion of the requirements for 
worker's PIA, but family benefits are limited to a maximum of 150 to about $188 \%$ of the worker's PIA, depending on the size of the PIA. ${ }^{214}$

The surviving spouse of an insured worker is entitled to receive a surviving spouse benefit equal to $100 \%{ }^{215}$ of the deceased worker's PIA $^{216}$ if the surviving spouse is age 65 or older. ${ }^{217}$ Surviving spouses as young as age 60 may elect to receive an actuarially reduced benefit. ${ }^{218}$ Again, working spouses are only entitled to receive a total benefit equal to the larger of their own worker's benefit or their surviving spouse benefit. ${ }^{219}$ In addition, a deceased worker's dependent children ${ }^{220}$ and parents $^{221}$ may also be eligible to receive a benefit equal to $75 \%{ }^{222}$ of the worker's PIA. However, total family benefits are limited to a maximum of 150 to about $188 \%$ of the worker's PIA. ${ }^{223}$

Social Security benefits are subject to a number of additional adjustments. ${ }^{224}$ For example, benefits are automatically adjusted according to increases in the cost of living. ${ }^{225}$ In addition, a Social Security "earnings" or "retirement" test reduces or even eliminates benefits for beneficiaries $^{226}$ who receive "excess" 227 earnings. ${ }^{228}$ Moreover, very low wage

children's benefits, see CCH, supra note 169, If 524; Stansbury, supra note 207, at 40-43.

214. See 42 U.S.C. 403(a) (1994). For a discussion of how the maximum family benefit is calculated, see 1998 GREEN BOOK, supra note 13, at 29-30; CCH, supra note 169, II 538; MYERS, supra note 2, at 90-94; see also STEURLE \& BAKIA, supra note 35 , at 81 .

215. If the deceased spouse received a reduced benefit prior to death, the surviving spouse is entitled to a benefit equal to the amount the deceased spouse would be receiving or $821 / 2 \%$ of the deceased worker's PIA, whichever is greater. See 42 U.S.C. § 402(e)(2)(D), (f)(3)(D) (1994); CCH, supra note 169 , II 525 , at 246.

216. If the insured dies before reaching age 62 , the surviving spouse benefit may be based on a specially computed PIA. See CCH, supra note 169 , I 525, at 246-47.

217. See SteUERLe \& BAKUA, supra note 35, at 80 . In a similar, though not identical, manner to the Normal Retirement Age for old-age benefits, the age for eligibility for full surviving spouse benefits is scheduled to increase gradually to age 67. See MYERS, supra note 2, at 51.

218. See CCH, supra note 169, II 525, at 246; MYERS, supra note 2, at 60.

219. See SteUerle \& Bakda, supra note 35, at 80; Burke \& McCouch, supra note 119, at $1214 \&$ n. 25.

220. See 42 U.S.C. \& 402(d) (1994).

221. See 42 U.S.C. \& 402(h) (1994).

222. If only one parent is eligible for the benefit, the benefit equals $82 \frac{1}{2} \%$ of the deceased worker's PIA. See 42 U.S.C. \& 402(h)(2)(A) (1994).

223. See Steuerle \& BAKUA, supra note 35 , at 81 . The earnings test was recently repealed for workers at or above the normal retirement age. See Public Law No. 106-182, 114 Stat. 198 (2000).

224. This section addresses the most significant of the adjustments. For a comprehensive discussion of Social Security's benefit provisions, see MYERS, supra note 2, at 47-129.

225. See 42 U.S.C. $\$ 415(i)$ (1994). For a more detailed discussion of the cost-of-living adjustments, see $\mathrm{CCH}$, supra note 169, II 541; MYers, supra note 2, at 101-07.

226. The "earnings test" applies to spouse/dependent benefits as well as worker benefits. See MYERS, supra note 2, at 121. 
workers may receive a special minimum benefit. ${ }^{229}$ Finally, 50 to $85 \%$ of the Social Security benefits of beneficiaries whose adjusted gross income exceeds thresholds as low as $\$ 25,000^{230}$ may be subject to income taxation. 231

227. In 1998, a beneficiary under the age of 65 could earn as much as $\$ 9,120$ without losing any benefits. Beneficiaries between the ages of 65 and 70 could eam as much as $\$ 14,500$ without losing benefits. Beneficiaries 70 years of age or older are not subject to the eamings test. See $\mathrm{CCH}$, supra note 169, I 555.1, at 277-78. Under the earnings test, one dollar is deducted from benefits for every three dollars earned over the annual exempt amount for people who have reached the normal retirement age. For people who have not yet reached the normal retirement age, one dollar is deducted from benefits for every two dollars earned over the annual exempt amount. See id.

228. See 42 U.S.C. $\$ 403(b)$ (1994). For a detailed discussion of the "earnings test," see CCH, supra note 169, 1555.1 ; MYERS, supra note 2, at 121-28.

229. See 42 U.S.C. $\$ 415(\mathrm{a})(1)(C)$ (1994). For a discussion of how the special minimum benefit is calculated, see STEUERLE \& BAKJA, supra note 35 , at 79 \& n.16 (noting that it affects less than one percent of OASDI recipients). See also CCH, supra note 169, I 537; MYERS, supra note 2, at 87-88; 1998 GREEN BOOK, supra note 13, at 25-26.

230. Single taxpayers whose adjusted gross income is between $\$ 25,000$ and $\$ 34,000$ may be subject to tax on one-half of their Social Security benefits. Married taxpayers filing jointly may be subject to tax on one-half of their Social Security benefits if their adjusted gross income is between $\$ 32,000$ and $\$ 44,000$. Single taxpayers whose adjusted gross income equals or exceeds $\$ 34,000$ may be subject to tax on $85 \%$ of their Social Security benefits. Married taxpayers filing jointly may be subject to tax on $85 \%$ of their Social Security benefits if their adjusted gross income equals or exceeds $\$ 44,000$. See 26 U.S.C. $\$ 86$ (a), (c) (1994). See also 1998 Social SeCurITY EXPLAINED, supra note 169,9255 , at 79 .

231. See 26 U.S.C. $\S 86$. For a more detailed discussion of taxation of Social Security benefits, see $\mathrm{CCH}$, supra note 169 , 9 II 250, 255. STEUERLE \& BAKJA, supra note 35, at 81-83: MEYERS, supra note 2 , at $146-50$. 